\title{
Editor's Introduction: \\ I. Writing Modern Art and Science - An Overview; II. Cubism, Futurism, and Ether Physics in the Early Twentieth Century
}

\section{Linda Dalrymple Henderson}

The University of Texas at Austin

\section{Writing Modern Art and Science - An Overview}

This issue of Science in Context presents a sampling of current work by art historians examining modern artists' engagement with science as well as the relationship of photography to both science and art. The essays' topics span the mid-to-later nineteenth century to the $1960 \mathrm{~s}$ and, thus, in a series of case studies provide an introduction to aspects of artistic modernism. Indeed, it is impossible to understand fully many of the radical innovations of modern art without some knowledge of an artist's cultural context, and developments in science have often played a critical role in defining that milieu. Collected together, these essays also represent methodological models of historical work on art and science that serve as useful examples in this developing field.

Part I of the Introduction surveys the history of writing on art and science, noting near its conclusion the later twentieth-century trends in the history of science and science studies that have problematized the conception of science as the unified field of activity it was taken to be for much of the period in question. Similarly, both the expansion of definitions of art itself in the second half of the twentieth century and the recent methodological interest in addressing visual culture more broadly have enlarged the art side of the comparison as well. ${ }^{1}$ Of course, the terms science, art, and modernism have also had particular significations that varied over time throughout the period in

\footnotetext{
${ }^{1}$ See e.g., Hopkins 2000. Despite the dates in Hopkins's title, After Modern Art 1945-2000, art historians generally agree that the shift in sensibility to what has been termed "post-modernism" in art occurred in the late 1960s and 1970s; significantly, however many artists have continued working in styles grounded in modernism and still consider themselves modernists today. The essays by both Petersen and Goodyear in this issue provide a sense of the new forms of artistic activity that began to emerge in the 1950s. On art history and visual culture, see Elkins 2003.

The "sciences" addressed in this text are generally the hard sciences (i.e., physics, chemistry, biology, etc.), as well as related fields such as botanical and zoological morphology, physiology, psychology, and kindred disciplines. Because the topic of art and medicine emerged as an active field only in the later twentieth century, particularly in the face of the AIDS crisis, it is addressed only in passing herein - specifically in Barbara Larson's essay as well as in relation to the X-ray as medical image (see n. 26 below).
} 
question, as in the case of the Cubism/Relativity question addressed in Part II of the Introduction.

Although historical connections between modern art and science are the primary focus of this volume, there have been a variety of other approaches to the question of art and science since the 1940s, when the first concentration of writing on this topic emerged. Discussions of art and science have often centered on attempts to find their commonalities - most often in terms of creativity or aesthetics. Well before C. P. Snow's The Two Cultures of 1959, mathematician and literary critic Archibald Henderson addressed what he termed the "contemporary battle of the cultures" in a 1946 article in American Scientist, "Science and Art: An Approach to a New Synthesis." Acknowledging both the "exhilarat[ion]" and the "psychotic dread" produced by the atomic bomb's demonstration of science's power, Henderson sought to bridge the "gap between the humanist and the mathematician, between the artist and scientist" by demonstrating both the shared creativity ("imagination, fantasy, intuition") and the delight in "elegance" in mathematics and science and in the arts (Henderson 1946, 453, 356). ${ }^{2}$ Responding to the cultural crisis of the war, British physicist and art/music critic Martin Johnson had already made a similar attempt to overcome "scientific uneasiness in an unscientific community" in his book Art and Scientific Thought: Historical Studies Toward a Modern Revision of Their Antagonism, published in London in 1944. In addition to emphasizing the role of imagination in science and art, Johnson sounded early a theme that would become prominent in writing on the subject in the 1950s and 1960s: the centrality of "Form, Pattern, Structure, in material or mental images" in both science and art (Johnson [1944] 1949, 42, 137).

Henderson's focus on creativity would be echoed in countless subsequent discussions of art and science. Jacob Bronowski, for example, explored this subject in his introductory essay "The Creative Process" in a 1958 issue of Scientific American devoted to innovation in science. A 1987 exhibition at the Cleveland Museum of Art was devoted to Creativity in Art and Science, 1860-1960. Similarly, a 1993 symposium in Stockholm also explored "The Creative Process" (Henning 1987; Gustafsson, Howard, and Niklasson 1993), as did Arthur I. Miller's 1996 book Insights of Genius: Imagery and Creativity in Science and Art (Miller [1996] 1999). ${ }^{3}$ The periodical Leonardo: Journal of the International Society for the Arts, Sciences, and Technology, founded in 1968 by engineer-artist Frank Malina, has long been an important locus for discussions of art and science, including examinations of creativity in the two fields. ${ }^{4}$ In an editorial in the April 2004 issue of

\footnotetext{
${ }^{2}$ Henderson feared that "young 'veterans' of global warfare" would "demand an education dominated by mathematics, the physical sciences, engineering, and technology," thus threatening the humanities (Henderson 1946, 453).

${ }^{3}$ Miller had also addressed creative thinking and the role played in it by "visual thinking" in his 1984 book Imagery in Scientific Thought (Miller [1984] 1986).

${ }^{4}$ See also, e.g., "Creative Processes," Leonardo (1994) 27(3):181-209, a section of a special issue on "Art and Science: Similarities, Differences and Interactions"; and Emmer 1996, which includes an article on creativity (39-42) by Ilya Prigogine, who had also contributed to the Stockholm conference.
} 
Leonardo, "ArtScience: The Essential Connection," biologist and historian of science Robert Root-Bernstein emphasizes creativity once again as a basic link between science and art, as he has done in books such as Sparks of Genius of 1999 (Root-Bernstein 2004; Root-Bernstein and Root-Bernstein 1999).

The issue of "elegance" or, more generally, aesthetics as the commonality between art and science has been pursued in a variety of forums, including the 1978 collection On Aesthetics in Science, assembled by Judith Wechsler, an art historian teaching at MIT in close proximity to the Center for Advanced Studies in the Visual Arts, directed by artist Gyorgy Kepes (Wechsler 1978b). Kepes, who is one of the subjects of Anne Goodyear's essay in the current volume and for whose 1978 MIT retrospective Wechsler wrote an essay (Wechsler 1978a), played a vital role in the history that follows. "The Aesthetic Dimension of Science" was the subject of the 1980 Nobel Conference held at Gustavus Adolphus College, with the papers published under that title in 1982 (Curtin 1982). More recently, a 2003 special issue of Hyle: International Journal for Philosophy of Chemistry, edited by Tami Spector and Joachim Schummer, was dedicated to "Aesthetics and Visualization in Chemistry," opening with an essay by Nobelprizewinning chemist Roald Hoffmann, who has long been engaged with the issue of chemistry and art (Spector and Schummer 2003). ${ }^{5}$

Creativity and aesthetics had also surfaced as themes in a 1985 American Academy of Arts and Sciences symposium subsequently published in Daedalus and in book form as Art and Science in 1986 (Graubard 1986). That volume included the dissenting response by art historian and critic Leo Steinberg, "Art and Science: Do They Need to Be Yoked?" Here Steinberg argued against "unhistorical art-science analogies," noting, for example, that themes such as "elegance" or "delight" are hardly present in all works of art (Steinberg 1986, 3, 5-6). ${ }^{6}$ Well before this Thomas Kuhn had also rejected the cataloging of similarities between art and science in response to E. M. Hafner, Dean of Sciences at Hampshire College, at a 1967 University of Michigan conference published in Comparative Studies in Society and History in October 1969. Kuhn, in particular, emphasized distinctions between ends and means in science and art, asserting that while visual images and aesthetic values are goals for the artist, they are only tools for the scientist. Kuhn also noted the transformative effect on scientific images of their inclusion in art exhibitions, which had become standard practice by the 1960s (Kuhn 1969, 404). ${ }^{7}$ Oliver Botar's essay in this issue, "László Moholy-Nagy's 'New Vision' and the Aestheticization of Scientific Photography in Weimar Germany," explores the

\footnotetext{
${ }^{5}$ See, e.g., Hoffmann 1995, and Hoffmann and Torrence 1993. The special issue of Hyle also includes, among others, essays by Root-Bernstein ("Sensual Chemistry: Aesthetics as a Motivation for Research") and by James Elkins ("Four Ways of Measuring the Distance Between Alchemy and Contemporary Art").

${ }^{6}$ Steinberg concluded that the "animistic charge of art works - the vitality imputed to them by the receiver ... is what sets art apart, and so dissociates it from the propositions of science that any procedural similarity between what artists and scientists do pales into insignificance" (Steinberg 1986, 14).

${ }^{7}$ Hafner had also discussed abstraction as another commonality between science and art (Hafner 1969, 385-87). The same year Werner Heisenberg gave a paper in Salzburg on "The Tendency to Abstraction in Modern Art
} 
roots of this phenomenon, suggesting that the interpenetration between aesthetic and scientific values in photography was more subtle than Kuhn may have realized.

Cyril Stanley Smith's essay in the 1978 On Aesthetics in Science volume addressed "Structural Hierarchy in Science, Art, and History," and by mid-century a focus on structure and form had become a more fundamental means to compare the two realms (Wechsler 1978b, 9-53). ${ }^{8}$ As noted above, Martin Johnson had already highlighted the concern with "Form, Pattern, Structure" in both science and art in 1944 (Johnson [1944] 1949, 42). That was the main theme of the 1951 London conference Aspects of Form: A Symposium on Form in Nature and Art, assembled by Lancelot Law Whyte in conjunction with the exhibition Growth and Form at London's Institute of Contemporary Art (Whyte 1951). The immediate stimulus for the exhibition, organized by artist Richard Hamilton, had been D'Arcy Wentworth Thompson's 1917 classic study of morphogenesis, On Growth and Form (Thompson 1942). ${ }^{9}$ While Whyte acknowledged Thompson (and biochemist Joseph Needham's contribution was devoted to the biologist), Whyte explained the symposium's primary rationale as the "increasing awareness of the morphological character of many of the sciences, which are now seen to be concerned with complex structures or forms of particular kinds" (Whyte 1951, 237; see also ibid., 7). ${ }^{10}$ With a Preface by art critic/scholar Herbert Read, Whyte's volume brought together contributions on crystallography, astronomy, biology (including C. H. Waddington), gestalt psychology (including Rudolf Arnheim), art (Ernst Gombrich), and early cybernetics (Grey Walter). ${ }^{11}$ "Our

and Science" (Heisenberg 1974, 142-53). For the impact of Kuhn's The Structure of Scientific Revolutions of 1962 (Kuhn 1970) on the theorization of abstract art in the 1960s, see Jones 2000.

${ }^{8}$ Smith had already published the essay "Structure/Substructure/Superstructure" in Kepes 1965, 29-41; that essay, along with his On Aesthetics in Science text was reprinted in the collection of his essays A Search for Structure (Smith 1981).

${ }^{9}$ On Hamilton's exhibition, see, e.g., Moffat 2000.

${ }^{10}$ The year following Whyte's event Hermann Weyl would publish his classic volume on Symmetry (Weyl 1952), which celebrated the beauty of symmetry in art (especially ornament), biological forms, crystal structure and mathematics. Works such as Arthur Loeb's Space Structures: Their Harmony and Counterpoint (Loeb 1976), with a foreword by C. S. Smith, carried on the study of structural form in mathematics.

${ }^{11}$ Waddington's essay, "The Character of Biological Form," included a few examples of sculptures by Henry Moore and Jean Arp to illustrate what he deemed a true, growth-oriented “organic quality" in art. Gombrich's "Meditations on a Hobby Horse or the Roots of Artistic Form" was a first iteration of the theory of representation he would come to call "making and matching," which he developed in subsequent books such as Art and Illusion: The Psychology of Pictorial Representation (Gombrich 1960).

I have generally excluded the large field of art and psychology from this essay, but, in addition to Gombrich, there are two other authors - both grounded in gestalt psychology - who should be noted. Rudolph Arnheim, also a participant in Whyte's symposium, first published Art and Visual Perception: A Psychology of the Creative Eye in 1954 (Arnheim [1954] 1974); his Entropy and Art of 1971 addresses form in terms of order and disorder. Anton Ehrenzweig's The Hidden Order of Art: A Study in the Psychology of Artistic Form appeared in 1967 (Ehrenzweig 1967). Psychology is also the primary emphasis in Dolf Rieser's Art and Science of 1972 (Rieser 1972) and in Paul Vitz's and Arnold Glimcher's Modern Art and Modern Science: The Parallel Analysis of Vision (Vitz and Glimcher 1984). One of the most recent additions to the literature on perception and cognition is Inner Vision: An Exploration of Art and the Brain by neurobiologist Semir Zeki (Zeki 1999). 
theme is thus the realization of the unity of spatial form in the complex processes of physics, biology, psychology, and art," Whyte explained (Whyte 1951, 2). In hindsight, Grey Walter's presence at the conference was an early sign of the cybernetics and systems theory that would ultimately make it possible to deal more readily with "complex processes." 12

Both Whyte and Cyril Smith contributed to Kepes' 1965 anthology Structure in Art and in Science, in which Kepes argued, "Structure seems central to our time - the unique substance of our vision. The most powerful imaginative vision is structure-oriented" (Kepes 1965, ii). ${ }^{13}$ Kepes' vision of the unity of art and science also owed a debt to gestalt psychology, which he had encountered in Germany in the 1920s. Responding like others to the "chaos" of World War II, Kepes had argued in his 1944 book The Language of Vision that the education of vision was crucial to humanity's creation of and integration into a "new vital structure-order" in a "dynamic world" being redefined by science and technology (Kepes 1944, 12-14). Toward that end Kepes himself had organized a 1951 exhibition titled The New Landscape in Art and Science, which was published in book form in 1956. That exhibition and book, like his later Structure in Art and in Science, juxtaposed scientific images, including microphotographs, with works of art and architecture to demonstrate hidden patterns of order "where art and science meet on common ground" (Kepes 1956, 20, 24). ${ }^{14}$

In Germany, morphological comparisons of art and science were grounded in the writings of Goethe, Ernst Haeckel's Kunstformen der Natur (1904), Karl Blossfeldt's Urformen der Kunst (1928), and, as Botar's essay establishes, the biocentrism of Raoul Francé and its applications by Kepes' mentor, Moholy-Nagy. The other root of this tradition, with its focus on morphogenesis in biology, extended back to D'Arcy Thompson and, beyond him, to Theodore Cook's The Curves of Life (1914) and Spirals in Art and Nature (1903). A 1958 exhibition organized by the Basel Kunsthalle, Kunstformen der Natur, which simply found scientific photographs to match the configurations of a group of modern paintings, represents the superficial extreme of such formal comparisons (e.g., the juxtaposition of an electron micrograph of aluminum with a 1908 Cubist painting by George Braque) (Schmidt and Schenk 1960, 8, 58-59). If the Basel

\footnotetext{
${ }^{12}$ Whyte notes at the end of his "Chronological Survey on Form" (229-37) that "there is no sign as of yet of a simple and comprehensive method of describing the changing form or structure of complex relationships" (Whyte 1951, 237). Whyte's essay in Kepes' 1965 Structure in Art and in Science, "Atomism, Structure, and Form," is an open-ended report on the eve of the emergence of chaos theory and complex systems analysis, which concludes with questions such as "What is chaos, if forms emerged from it?" (Kepes 1965, 27). In the 1978 On Aesthetics in Science volume, C. S. Smith included a note with his bibliography, stating that just as he had excluded "mathematical treatments of group theory and algebraic topology," the "copious literature on systems analysis and that on structuralism in anthropology and linguistics is not cited despite some similarities in both problems and solutions" (Smith 1981, 390; Wechsler 1978b, 53).

${ }^{13}$ For Smith's essay, see again n. 8; for Whyte's essay, see again n. 12.

${ }^{14}$ Kepes' integrative social vision paralleled that of his mentor Moholy-Nagy; see the Goodyear essay herein. Kepes was also aware of the developing field of cybernetics, since Norbert Weiner was at MIT and contributed to Kepes' publications (see, e.g., Kepes 1956, 274-76).
} 
organizers sought to validate modern art in this way, Philip Ritterbush organized The Art of Organic Forms at the Smithsonian's Museum of Natural History in 1968 in order to "express the creative, imaginative character of science by demonstrating its affinities with the arts" (Ritterbush 1968, iii). Ritterbush's catalog text is noteworthy for its fine history of biology's investigation of form - from Goethe to the embryologist/geneticist Waddington. In 1969, Waddington, who had contributed not only to Whyte's Aspects of Form but also to Kepes' collection titled Module, Proportion, Symmetry, Rhythm (Kepes 1966, 20-37), demonstrated his own conclusions about "the underlying structure of things" in his book Behind Appearance: The Relations Between Painting and the Natural Sciences in This Century (Waddington [1969] 1970, jacket flap).

Waddington's Behind Appearance also addressed history to some degree, but before turning to the somewhat vexed issue of the historical relationships of modern art and science, it is useful to note more recent approaches to this subject that have crossed the borders between the disciplines or set aside the "binary economy" of art and science to consider this subject in new ways (Jones and Galison 1998, 2). Just as historians of science and science studies scholars have become increasingly interested in visual imagery, art historian James Elkins proposed in 1995 that art history should address "images that are not art" (the vast majority of images), including a variety of types of scientific illustrations and engineering drawings as well as "graphs, charts, maps, geometric configurations, notations, plans, some money, bonds, seals, stamps,... schemata, and pictographic or ideographic elements in writing" (Elkins 1995, 553; Elkins 1999, 3-4). Elkins demonstrated this approach in his 1999 book The Domain of Images and has recently argued for the inclusion of scientific images in the program of the new field of "visual studies" (Elkins 2003, 159-76). For their 1998 collection Picturing Science, Producing Art, art historian Caroline Jones and historian of science Peter Galison chose, as they say, to move beyond the separate categorization of art and science in order to explore overlapping philosophical and methodological issues in their histories. As a result, contributors "address questions of viewing and knowing in which both artistic and scientific practices are brought into consideration, among many other kinds of cultural practices and productions" (Jones and Galison 1998, 6). The sites of knowledge production explored are organized around the themes of Styles, The Body, Seeing Wonders, Objectivity/Subjectivity, and Cultures of Vision. ${ }^{15}$

In contrast to Jones and Galison's volume, the specific exploration of historical relations between art and science is our primary concern here, and a look back at the development of this field provides a perspective on the debates that continue to

\footnotetext{
${ }^{15}$ In their introduction Jones and Galison also note the work of eighteenth-century scholar Barbara Maria Stafford, who has been a pioneer in examining (and defending) visual language in art and in fields such as medicine and science; more recently Stafford has engaged digital imagery as well. See, e.g., Stafford 1996, among other titles. In terms of modernism, note should also be made of the work of one of the contributors to the Jones and Galison volume, Jonathan Crary, on changing conceptions of vision and the observing subject in relation to nineteenth-century psychology and physiology. See, e.g., Crary 1990.
} 
surround it. ${ }^{16}$ The first extended discussions of historical connections between modern art and science appeared in the 1940s. More general analyses of the relations of science and the humanities had a longer history - especially in Britain - but World War II and the atomic bomb brought this topic to the fore with a new kind of urgency. ${ }^{17}$ Within the art world there were additional new reasons to explore the suggestion made as early as 1921, but far more widely in Sigfried Giedion's Space, Time and Architecture of 1941, that Picasso's Cubism had some connection to Relativity Theory and Einstein. ${ }^{18}$ Cubism and modern art in general still perplexed much of the general public, and, while Relativity Theory was hardly well understood, the aura of Einstein, who had come to stand as the emblem of twentieth-century science, offered a means to validate the formal inventiveness of Picasso's Cubism. ${ }^{19}$ Much of the writing on art's relationship to science was done against this backdrop in the 1940s, and - unable to fathom how Picasso might have engaged Relativity Theory - authors proposed far more nebulous circuits of information or fell back on the notion of a Zeitgeist to explain the supposed connection. $^{20}$

For example, the painter Wolfgang Paalen wrote in his 1944 essay "On the Meaning of Cubism Today" of Cubist painting's incorporation of time and resultant arrival at a "continuum of space-time unknown until then in painting." Paalen was one of the artists most conversant with science in this period, as Gavin Parkinson's essay herein establishes, and he continued, "Such analogies in no way indicate that cubism has ever been a scientific art... but only that great thoughts in the same period often follow

16 The following overview focuses primarily on English-language books and not on journal articles. For the rich periodical literature in this field, see, e.g., such databases as Artbibliographies Modern (art + science), as well as published bibliographies, such as the "Relations of Science to Literature and the Arts" (originally "Relations of Literature to Science") published from 1993 to 2001 in Configurations: A Journal of Literature, Science, and Technology, the organ of the Society for Literature and Science (SLS) and now available on the group's website (www.litsci.org). In recognition of its greater involvement with visual imagery, that group voted in 2004 to change its name to the Society for Literature, Science, and the Arts (SLSA). The website of the journal Leonardo (MIT Press) features an annotated bibliography, "The Visual Arts and Natural Sciences in Historical Perspective," compiled in 2003 by David Topper, who, with John H. Holloway, had earlier published bibliographies on the "Interrelationships between the Visual Arts, Science, and Technology" in Leonardo 1980, 13(1) and Leonardo $1985,18(3)$.

${ }^{17}$ On this background, see Porter 1994, and the introduction by Stefan Collini to Snow 1998.

${ }^{18}$ Lynn Gamwell has located what may be the first published reference linking Einstein and Cubism in Czech art historian Vincenc Kramár's 1921 book Cubism, where he connected the style to "the transformation of our idea of the world, as reflected in Einstein's theory and in studies of the fourth dimension" (Gamwell 2002, 139). For Giedion's argument, which was first presented in his Charles Eliott Norton Lectures at Harvard in 1938-39, see Giedion 1941, 355-57.

${ }^{19}$ For a detailed discussion of this process, see Henderson 2005.

${ }^{20}$ For a critique of the Zeitgeist, see, e.g., Topper 1988. The most egregious example of this approach applied to Picasso and Einstein is California surgeon Leonard Shlain's Art and Physics: Parallel Visions in Space, Time, and Light of 1991. Drawing on the ideas of Jung and Teilhard de Chardin, Shlain argues for the existence of a disembodied "universal mind" that he believes "spacetime generates" (Shlain 1991, 429). According to Shlain, "Universal mind would be the moving force behind our zeitgeist, speaking through the works of revolutionary right-brained, intuitive artists first, and later through left-brained, visionary, rational physicists" (ibid., 430). 
parallel ways without their authors being aware of it" (Paalen 1945, 27-28). ${ }^{21}$ In a similar manner critic Clement Greenberg asserted in his essay "Our Period Style" in 1949, "The affinity between the new style in the visual arts and modern physical science should be obvious from the terms in which I have described the former." However, it was not "a matter of the modern artist being influenced by science," he added. Rather, Greenberg, like virtually all of the advocates of the Cubism-Relativity hypothesis, saw the connection in vaguer terms: "[The artist's] relation with science... is owed to the fact that, in our age as in every other, the highest aesthetic sensibility rests on the same basic assumptions, conscious or unconscious, as to the nature of reality as does the advanced thinking that is contemporaneous with it" (Greenberg [1949] 1986, 325). Art historian Paul Laporte, in two oft-cited articles of 1948 and 1949, argued more specifically for "correlations" between Cubism and Relativity Theory that could explain the seemingly "wilful" distortions in Picasso's paintings as the result of the changing relationship of the artist and object in space-time, embodied as the "spatial graphic expression of time" (Laporte 1948, 27, 30). ${ }^{22}$

Most discussions of modern art and science in subsequent decades were haunted and hence skewed by the supposed Einstein-Picasso connection, which led authors to speak in the vague terms of Paalen or Greenberg, to cite Laporte as evidence that strong parallels suggested an innate connection between the two, or to deny altogether that Cubism could have had anything to do with science. Noting Laporte's texts, Edward Fry came to the latter conclusion in his 1966 anthology Cubism: "While undoubtedly a rough metaphorical parallel may legitimately be made, it would seem dangerous to extend it too far, or to seek exact correspondences in this period between the two realms of human activity, which in the early twentieth century were hardly as interrelated as they were in the Renaissance or even in neo-impressionism" (Fry 1966, 119-120). And art historian Meyer Schapiro, who had been observing the developing Cubism-Relativity literature from the 1940s onward, argued vehemently against the connection in lectures or in private musings, which were only published posthumously (Schapiro 2000). ${ }^{23}$ Fry, Schapiro, and others seem never to have considered the

\footnotetext{
${ }^{21}$ On Paalen and science, see also Parkinson 2005 and Winter 2003. The writings of Paalen, Greenberg, and Laporte are discussed in greater detail in Henderson 2005.

${ }^{22}$ Laporte himself published in 1966 a 1946 letter from Einstein asserting that he had misconstrued Relativity Theory in his attempt to tie it to multiple viewpoints in Cubism (Laporte 1966, 246). Gerald Holton discusses this exchange and further clarifies the error in the frequent misinterpretation of Relativity Theory as signifying that "all frameworks, points of view, narrators, fragments of plot or thematic elements are created equal" (Holton 1996, 131).

${ }^{23}$ As Lillian Schapiro explains in the Preface, "The text 'Einstein and Cubism: Science and Art' has been edited by Dr. Joseph Masheck ... from a great mass of competing draft sheets, revisions, supplements, and notes that had grown out of a lecture delivered in 1979 at the Hebrew University of Jerusalem symposium commemorating the centenary of Albert Einstein's birth" (Schapiro 2000, vii). It is a tragedy that Schapiro never consolidated or updated his thoughts, since this rambling text sans footnotes does not do justice to this great art historian.

The Einstein centennial was also marked by the collection of essays Einstein: The First Hundred Years. In contrast to Schapiro's critique, the essay on "Einstein and Art" by painter Philip Courtenay focused primarily
} 
possibility that other "sciences" besides Relativity Theory might have been stimulating the imaginations of artists and writers in the early years of the twentieth century.

Waddington carried forward the Cubism-Relativity discussion in his 1969 Behind Appearance, although he also noted in passing the challenges the discovery of radioactivity and of the electron represented to conceptions about the nature of matter in this period. However, Waddington's primary focus in addressing Cubism was on the changed conceptions of space and time wrought by Relativity Theory, and he like others before him - pointed to the references by the poet Guillaume Apollinaire to the "fourth dimension" in Cubist literature as corroborating evidence. Waddington nonetheless notes Apollinaire's highly poetic language ("the fourth dimension of space... represents the immensity of space eternalizing itself") and argues that the poet had "no grasp of the scientific principles he was referring to." He also observes that these artists and writers would not have been "mathematically equipped to grasp Einstein's ideas, at a time long before these had been expounded for non-scientific readers" (Waddington [1969] 1970, 15). This is a crucial point: Relativity Theory simply was not popularized in France in time for it to have had any direct impact upon Cubist painting. ${ }^{24}$ Here, too, is the germ of a more general lesson about historical interactions of modern art and science: popular scientific literature has been a crucial link between artists and science in the twentieth century.

The "fourth dimension" or non-Euclidean geometry were both important elements of cultural discourse in the early twentieth century. However, they were not reflections of Relativity Theory but rather of the popular fascination with alternative models of space derived from nineteenth-century geometry, information that I first published in 1971 and followed up in my 1983 book The Fourth Dimension in Non-Euclidean Geometry in Modern Art (Henderson 1971; idem 1983). ${ }^{25}$ As in the case of the fourth dimension, a conscious archeological recovery of science as popularly understood is necessary in order to evaluate the possibility that Cubism owed a debt to recent developments in "science." Waddington was on the right track in noting radioactivity and the electron, and his interest in transparency in Cubism might have led him to discover the other sensation of popular science in the early years of the century - the X-ray, a subject

on Cubism and included such statements as "Cubism attempted to incorporate Einstein's fourth dimension to gain 'realism of conception," and "How much modern art was aided by Einstein's ideas is an open question; that it was aided is not" (Courtenay 1980, 152, 156).

${ }^{24}$ Einstein became a celebrity only in 1919, when experiments during an eclipse confirmed one of the predictions of his theory. For the delayed response to Einstein and Relativity Theory, see, e.g., Kragh 1999, 98-104, as well as Henderson 1983 (app. A). On the looming figure of Henri Poincaré in France and the general silence that met Einstein's theories, which Poincaré rejected, see Goldberg 1984, chap. 7, and Glick 1987, 113-67.

${ }^{25}$ Independently, John Adkins Richardson argued in his Modern Art and Scientific Thought that "Cubism has nothing to do with the Theory of Relativity and that is the end of the matter" (Richardson 1971, 112). Although Richardson noted in passing the existence of a popular "fourth dimension" of space, he chose instead to compare Cubism to developments in modern logic; his goal, he has said more recently in a review of the books by Waddington, Vitz and Glimcher, and myself, was "not the discovery of truth so much as the revelation of synoptic commonalities" (Richardson 1985, 90). 
treated, along with radioactivity and the ether of space, in Part II of the Introduction below. ${ }^{26}$

Waddington was far more sanguine about art-science relationships after World War II, when he believed that artists had actually assimilated scientific information "at a deeper level" (Waddington [1969] 1970, 240). He knew a number of contemporary artists, such as Ben Nicholson, Barbara Hepworth, Henry Moore, and Kepes, and, having lived through the period, he was more generally aware of the information about science that was readily available to artists. In particular, Waddington was interested in contemporary biology, atomic theory, and the developing field of cybernetics. Instead of exploring specific historical connections, however, Waddington's later chapters juxtaposed separate histories of scientific developments and histories of art, allowing morphological comparisons to suggest general parallels. For Waddington, in the end, it was at the base level of creativity that art and science were in "true communication" (Waddington [1969] 1970, 242). ${ }^{27}$ Thus, in contrast to Stephen Petersen's discussion of painter Roberto Crippa in the context of the Italian "Nuclear Art" movement in this volume, Waddington simply illustrates one of Crippa's works suggestive of orbits within the atom to demonstrate the concern with hidden processes and energy on the part of the new painters (fig. 97 in Waddington [1969] 1970).

Like Waddington, Leo Steinberg in a 1953 Partisan Review essay, "The Eye is Part of the Mind," had noted the shared emphasis in contemporary art and science on "nature in its latest undisguise." Moreover, according to Steinberg, artists whose energy-filled canvases representing "trajectories and vectors, lines of tension and strain," might well augment the "visual imagination" of culture at large by "schooling our eyes to live at ease with the new concepts forced upon our credulity by scientific reasoning" (Steinberg 1953, 211). Waddington, too, believed that art could contribute to the growth of science and culture, asserting, "Looking at paintings, or experiencing other kinds of art, especially kinds which are not too immediately transparent... is one of the best ways for a scientist to loosen the joints of his psyche, to 'roll the bones' of his ideas, and give himself a chance to dredge up from the obscure internal depths something... which may be fresh enough to be worthwhile" (Waddington [1969] $1970,242)$.

\footnotetext{
${ }^{26}$ For an initial discussion of the importance of the X-ray and radioactivity for art in pre-World War I Paris, see Henderson 1988. Asendorfs Ströme und Strahlen (1989) was another of the studies that first examined the turn-of-the-century science known to the general public. Kevles 1997 addresses the X-ray in the context of the history of medical imaging and the response of artists and the public to its various phases of development.

${ }^{27}$ On Waddington's background and debt to A. N. Whitehead's holism, see Porter 1994, 77-79. Martin Kemp has argued that "the discerning of fundamental qualities of structure and process in nature" in the morphogenesis of D'Arcy Thompson and in the method of Waddington's Behind Appearance (but now "undertaken with a full awareness of the historical, cultural, and scientific factors") offers "a particularly promising agenda for the cognate histories of the visual in biology and art" (Kemp 1996, 29). Kemp, writing in an issue of the Art Journal devoted to "Contemporary Art and the Genetic Code" was arguing against losing sight of morphogenesis in the rush to embrace the genetic code. For a sampling of contemporary artistic responses to genetics, see Levy and Sichel 1996.
} 
The impact of art on science has always been the direction less discussed. The best-known case of art's contribution to science may be Galileo's debt to artistic chiaroscuro modeling techniques for his reading of the moon's craters (see, e.g., Edgerton 1984a; Bredekamp 2000). Recently, however, Root-Bernstein has argued that there are numerous instances of science's debt to art, including the centrality of Buckminster Fuller's geodesic domes and tetrahedral structures for scientists modeling the polio virus in the 1950s and the "buckminsterfullerene" molecule in the 1980s (Root-Bernstein 2000, 134). ${ }^{28}$ An artist's powers of visualization, in particular, can contribute to scientific or mathematical insight. Topologist Scott Carter, who studies two-dimensional surfaces knotted in four-dimensional space, reports having had an experience akin to Waddington's in front of a painting by artist Tony Robbin. In this series of works, which includes the large-scale Fourfield of 1980-81, Robbin combined a complex, geometrically patterned background with both wire constructions and painted outlines representing pairs of slightly shifted sections of the four-dimensional hypercube (see Robbin 1992). According to Carter, "Tony's painting spoke directly to me since I had seen glimpses of 4-space in my own research. He had escaped the plane of the canvas in order to explain escaping the plane of the 3-dimensional world." 29

In 1981 the University of Edinburgh, where Waddington had held a chair from 1945 until his death in 1975, sponsored the conference Common Denominators in Art and Science. Acknowledging Waddington's importance to the field, the co-organizers emphasized that their goal was to use an "historical approach" to "uncover similar operative factors in art and science through a study of the work and working methods of selected artists and scientists in the historical period chosen" (Pollock 1983, xiv). ${ }^{30}$

\footnotetext{
${ }^{28}$ Fuller had contributed an essay entitled "Conceptuality of Fundamental Structures" to Kepes' 1965 Structure in Art and in Science volume, and his work can be recognized as part of the larger concern with morphology and structure discussed above.

${ }^{29}$ Scott Carter e-mail to the author, Aug. 3, 2004. He continued, "Having spent time staring at facimiles of Tony's paintings, and playing with some of his computer programs, I came to want to develop some programs of my own that showed the objects with which I work. Lately, I have been working with these." For Robbin's deep engagement with mathematics and physics, including quasi-crystals, see Robbin 1992. See also his forthcoming book from Yale University Press, in which he addresses the history of visualizations of four-dimensional geometry, including a close rereading of Minkowski's papers of 1907 and 1908 that interprets the space-time continuum as based on a geometry of projection rather than the common interpretation of a slicing of worldlines. Robbin's text also recounts his interactions with quantum physicist P. K. Aravind, for whom four-dimensional projective geometrical figures have become important to his research on particle entanglement.

Artists have contributed more often to technological developments, as Goodyear's essay documents in terms of the number of patents that resulted from the artist-engineer collaborations for E.A.T.'s 1966 “Nine Evenings: Theater and Engineering." The work of photographer Felice Frankel in assisting scientists "to make good pictures of good science" stands as another contribution of artistic vision to science, in this case in terms of the effective presentation of results. See, e.g., Envisioning Science: The Design and Craft of the Science Image (Frankel 2002, 2).

${ }^{30}$ Mathematician and filmmaker Michele Emmer showed his films on M. C. Escher and on the Möbius band at the Edinburgh conference, introducing them with "Some Remarks on the Relationship of Art and Mathematics" (Pollock 1983, 90-96). Emmer has been a leading figure in the field of art and mathematics, producing a large bibliography of writings and films, organizing a yearly "Matematica e Cultura" conference
} 
Among the contributions were historian of science Alex Keller's paper "Continuity and Discontinuity in Early Twentieth-Century Physics and Early Twentieth-Century Painting" and Peter Lloyd Jones' recollection of his design education in the context of the rising tide of cybernetics and information theory in the 1960s (see Pollock 1983, 97-106, 149-59). Keller discusses aspects of the history of science that are very relevant to artists of the pre-World War I period. However, his essay focuses instead on the Neo-Impressionism of Georges Seurat and Paul Signac, with its application of pure color in discrete dots, which in Signac's subsequent works became brick-like marks. Keller notes only at the end of his text the later adoption of the Neo-Impressionist brick-like stroke by Matisse and Picasso (see, e.g., fig. 2 herein). ${ }^{31}$

Jones in his essay "Science and the Zeitgeist in the 1960s" rejects an immaterial Zeitgeist, noting his "personal inclination towards explanations of cultural diffusion in terms of the contingent interactions of persons through specific institutions of communication: books, articles, academic lectures and seminars, art galleries, and magazines." He also proposes that for a scholar with a less intimate historical knowledge of a period, studying the language "flow [ing] between science and art" (i.e., "software,' "information,' 'code"' in the 1960s) would be a more useful strategy than the quest for "common denominators" (Jones in Pollock 1983, 157-58). Both of these suggestions are relevant to the method I propose further below.

The Edinburgh conference was also a barometer of new trends in the field of history, registering the impact of the ideas of Michel Foucault, in particular, in the contributions of philosopher Rom Harré and design historian/theorist Gérard Mermoz. ${ }^{32}$ Here linguistic structuralism and early post-structuralism met the morphological tradition of Waddington. In "On the Synchronization between Artistic Practices: An Exploration of Hypotheses, 1900-1930," Mermoz not only criticized any resort to a "Spirit of the Age," but also directed a pointed critique toward what he termed "Art History and the search for "influences,", associating it with "the mechanistic model (causeeffect)" (Mermoz 1983, 134-36). Citing Picasso's denials of connections to science as well as the negative comments of Werner Heisenberg and George Kubler on the subject of science's impact on modern artists, Mermoz argues that Picasso's disclaimer of external influences "proclaims the irrelevance /irreverence of the search for influences"

in Venice with published proceedings, and editing The Visual Mind: Art and Mathematics (1993) and The Visual Mind II (2004) for MIT Press (see Emmer 1993 and Emmer 2004).

31 "This divisionism then is the expression of a discontinuity of substance which adds up to the apparent visible continuity" (Keller in Pollock 1983, 105). As discussed in Part II of this essay, with the continued dominance of the ether in this period, it was the "apparent visible continuity" that still dominated, particularly since the very existence of the atom was established empirically by Perrin only in 1909 (see Nye 1972, 126-36). On the Neo-Impressionists' debt to contemporary discussion of the chemical atom, see Roslak 1991, which should be considered against the backdrop of Robert L. Herbert's pioneering work on Seurat and conceptions of art and science in his time (e.g., Herbert 1991).

${ }^{32}$ Harré's essay, "What Is the 'Zeitgeist'? Prospects and Problems for the Investigation of the Interaction of Arts and Sciences," argues for a "deep-structure form of explanation of correlations," which may be supported by a "common metatheory" (Pollock 1983, 4). 
(Mermoz 1983, 135-36). Instead, citing Roman Jakobson and Foucault, he proposes the investigation of deep "structural correlations" between art and science that exist between "the various semiological functions of each discourse ... and 'extradiscursive' formations." 33 Unfortunately, Mermoz does not put his methodological proposal into practice in his essay. However, his quest for "structural correlations" would subsequently be embraced by literature scholar Thomas Vargish and physicist Delo Mook as a means to argue, once more, the Cubism-Relativity case in their 1999 book Inside Modernism: Relativity Theory, Cubism, Narrative. ${ }^{34}$

Foucault's ideas would have a profound impact in the 1980s and 1990s on historians, including both those of science and of art, and his focus on discourse analysis can indeed be extremely fruitful. However, Mermoz's resistance to examining an artist's sources closes off the very possibility of understanding a creative individual in his or her historical context. To accept uncritically Picasso's denial of "influences" and to privilege the "sovereignty of his creative process," as Mermoz does, is a highly questionable stance for an historian, especially one arguing for a "more critical attitude towards quotation data" (Mermoz 1983, 136-37). ${ }^{35}$ Picasso's comments themselves are clearly responses to particular situations in the art world in a given period: in the 1920s he decried art defined as "research," and in the 1950s he claimed that all his art was research. Denying he had ever read anything scientific in a 1923 interview, in 1956 significantly the year after Einstein's death had led to new adulation - Picasso declared, "When I read a book on Einstein's physics of which I understood nothing, it doesn't matter; that will make me understand something else" (Ashton 1972, 3, 6, 71, 72).

\footnotetext{
33 The specific Foucault reference for Mermoz is "Politics and the Study of Discourse," published in Ideology and Consciousness, where Foucault uses the term correlation, but not the "structural" adjective both Harré and Mermoz adopt (Foucault 1978).

${ }^{34}$ Drawing on both Mermoz's model of "structural correlations" and Katherine Hayles' idea of a "field theory of culture" (Hayles 1984, 22-23), Mook and Vargish establish three "cultural diagnostics" by which to investigate modernism across fields: Relativity Theory, Cubism, and narrative in modern literature. Although they acknowledge the accuracy of historical arguments against any connection between the ideas of Einstein and Picasso, they argue that their cultural diagnostics will nonetheless expose "common values that find contemporaneous expression in disparate fields" and stand as "constituent[s] of Modernism" (Mook and Vargish 1999, 4-5). For a discussion of the problems with the Mook and Vargish book, including their dependence on Greenberg's writings on Cubism from the 1940s, which are inflected by the critic's own engagement with the language of Relativity Theory, see Henderson 2005. Mook and Vargish's section on literature is more successful than that on Cubism, since, as Alan Friedman and Carol Donley have established, a number of modern writers responded to Relativity Theory as popularized (Friedman and Donley 1985). But the continued focus on Picasso and Einstein, while useful perhaps for broad characterizations of the twentieth century, tells us nothing about the cultural milieu in which Picasso was actually operating.

${ }^{35}$ Mermoz quotes sculptor Naum Gabo asserting that "the creative processes in the domain of Art are as sovereign as the creative processes in science" (Mermoz 1983, 136). However, like Picasso, Gabo clearly had an agenda of self-promotion; moreover, as Martin Hammer and Christina Lodder have established, his ideas on art and science developed in response to sources such as Sir James Jeans, Sir Arthur Eddington, and Bertrand Russell as well as D'Arcy Thompson (Hammer and Lodder 2000, chap. 14). Having met Kepes in Germany in the 1920s, Gabo wrote his essay "Art and Science” for Kepes' The New Landscape (Kepes 1956, 61-63).
} 
Mermoz had quoted Heisenberg's assertion in 1958, "There is little reason for thinking that modern science has had a direct influence on, say, the artist's discourse with nature"; he quoted Kubler in 1962: "There are few signs that the basic theoretical ideas of science affect artists very much" (Pollock 1983, 135-36). However, Heisenberg and Kubler should hardly be taken as the last word on the subject of artists' responses to science. In Heisenberg's talk on "The Tendency to Abstraction in Modern Art and Science" at a 1969 symposium on "The Significance for Art of the Findings and Discoveries of Modern Science," the physicist confessed, "I know the history of art only at second hand, have not studied it in detail and am therefore in danger of judging superficially" (Heisenberg 1974, 143).

Kubler had made his remark at the 1967 University of Michigan symposium, and, paralleling Kuhn's comments cited earlier, he had reacted to what he described as E. M. Hafner's seeming "to smother contemporary art under a blanket comparison with science" (Kubler 1969, 398). In his 1962 book The Shape of Time Kubler had adopted the language of energy transmission and information theory as a model for the history of style in art, replacing the prevalent biological metaphor (Kubler 1962, 9). With biological morphology as the primary terrain on which art/science comparisons had been made for two decades, Kubler in his response seemed determined to play down any innate connections between art and science. ${ }^{36}$ Unbeknownst to Kubler and contrary to his assertion that scientific theories held little interest for artists, his own book had recently served as a stimulus for artist Robert Smithson's developing entropy-oriented art and theory, which was grounded in his extensive collection of science books, including P. W. Bridgman's The Nature of Thermodynamics. ${ }^{37}$ During the1960s Kubler's own "pluralistic vision" of history would draw crucial support from Bohr's theory of complementarity, especially as set forth by Gerald Holton in Daedalus in $1970 .{ }^{38}$

\section{A Methodological Interlude}

Given Mermoz's reduction of art history to a "search for influences," a moment of clarification is necessary. In his 1985 book Patterns of Intention: On the Historical Explanation of Pictures, Michael Baxandall wisely urged art historians to reject the term influence. In his "Excursis against Influence" Baxandall argued convincingly for

\footnotetext{
${ }^{36}$ Kubler concluded by asserting that artists and scientists "resemble each other more as artisans than as intellectuals" (Kubler 1969, 402).

${ }^{37}$ For Smithson's science and technology books, see the listing in Reynolds 2003, 338-43. On Smithson and Kubler, see ibid. and Lee 2001.

${ }^{38}$ On Kubler and complementarity as well as his debt to Holton, see the introduction by Thomas F. Reese in Kubler 1985, xxx. Kubler's The Shape of Time was a response to his mentor Henri Focillon's La Vie des formes, written in 1934, which Wittenborn published in Kubler's translation in 1948 (see Kubler 1985, xxvi-xxvii). Focillon's morphological study appeared in Whyte's "Chronological Survey on Form" (Whyte 1951, 248). Burnham also addresses Focillon in the context of organicist aesthetics (Burnham 1968, 77-79).
} 
replacing the passive connotation of "influence" with a model of the artist as a proactive seeker of information on those issues that are of interest (Baxandall 1985, 58-62). Although Baxandall's subject was artistic sources, the same model applies for any aspect of the discursive field that forms an artist's cultural context. Art grows from art, and an artist picks and chooses what seems relevant both from past art and from the cultural milieu in which he or she operates. By focusing on sources and choices, there is no longer the vague imprecision of "influence" or the suggestion that an artist has responded passively or mechanically in a cause-effect scenario.

Behind this method lies what Baxandall has termed his "skeptical intentionalism," or the belief that, despite poststructuralist arguments to the contrary, we can indeed recover to some degree an artist's basic intentions (Baxandall 1985, vii, 58-62). More specifically, as artist/art historian Charles Harrison has argued, "If we are adequately to assess artists' intentions and actions in the light of historical conditions, it will be necessary to include among those conditions what it was possible to imagine" (Harrison 1993, 226). While Harrison was actually addressing political utopianism in this statement, contemporary scientific developments and discoveries have a profound effect upon what an artist believes about reality or can imagine as a future prospect. We will never know exactly what an artist was imagining, but a recovery of the science readily available to the public - whether written by scientists themselves or by science writers - is vital in order to establish the parameters of what was possible at a given moment. This popular literature, preserved primarily in newspapers, magazines, and popular books, is a critical interface between art and science. With the advent of paperback editions of books on science and mathematics by publishers such as Dover, the amount of information accessible to an interested artist in the 1950s-1960s (e.g., Smithson) increased significantly, and television and the internet have expanded this information exponentially. ${ }^{39}$

Popularized science would be an important part of the "cultural field" model Katherine Hayles proposed in her 1984 book The Cosmic Web in opposition to arguments for mechanical causality via "direct lines of influence" between science and literature. According to Hayles, it is this "societal matrix" or, "in Whitehead's phrase ... a "climate of opinion"" that makes certain questions interesting to pursue at a certain time. She also emphasizes that "in a field model, the interactions are always mutual: the cultural matrix guides individual inquiry at the same time that the inquiry helps to form, or transform, the matrix" (Hayles 1984, 22-23). Borrowing Hayles' idea of the "cultural matrix" and anchoring it historically by analyzing available popular

\footnotetext{
${ }^{39}$ By mid-century Scientific American had attracted a good deal of interest among artists and critics, such as Richard Hamilton and Lawrence Alloway of the Independent Group in London in the 1950s (see, e.g., Robbins 1990, 29). From the 1960s to the present U. S. sculptor Athena Tacha, for example, has been an assiduous reader of that journal, along with a multitude of science books (personal communications from the artist). On Tacha's artistic response to the morphological tradition as well as to quantum physics and chaos theory, see Trulove 2000 .
} 
sources on science, we will never know all that the matrix contained, but we can be fairly certain of what it could not contain. In pre-World War I Paris, that was accessible information about Einstein and Relativity Theory. Popular scientific literature, along with the writings of artists and critics, is ripe for the discourse analysis Mermoz, following Foucault, proposed.

One last methodological clarification should be made in response to an objection Elkins raises in his article on "Art History and Images That Are Not Art" concerning the work of art historians who explore historical relations between art and science (Elkins 1995, 555). Because his own essay was centered on images, Elkins addresses such scholarship as if it dealt only with visual images, with art historians "work[ing] to explain pictures by locating the relevant scientific sources." He concludes:

There are both historical and methodological limitations that prohibit the approach from doing wider justice to the relations between science and art.... Since the search for scientific sources depends on specific iconographic parallels, ... it cannot come to terms with more abstract influences on twentieth-century art, such as popular notions of the uncertainty principle, nuclear fission, and fractal geometry.... Ultimately the approach lacks the flexibility to demonstrate the full relation between science and art - what twentieth-century art is not influenced by modern science? - and it does not yet possess a methodological strategy that would justify concentrating on more literal parallels. (Elkins 1995, 555-56)

It may be true that the emphasis in early scholarship on historical connections between art and science was weighted toward images, including the two fine 1984 Art and Science issues of the Art Journal, edited by Renaissance art historian Samuel Edgerton, a pioneering figure in this area (Edgerton 1984b). Since a portion of the artscience field has always been devoted to optics and perspective and the primary work of art historians has been image-based, this orientation is not surprising - especially when carried out in the context of traditional museum exhibitions, such as Jean Clair's L'Ame au corps: Arts et sciences 1793-1993 (Clair 1993) or his Cosmos: From Romanticism to Avant-Garde (Clair 1999). ${ }^{40}$ However, the most striking visual comparisons are generally complemented by textual analyses, and even the essays in exhibition catalogs, such as that by Science in Context contributor Barbara Larson on nineteenth-century French astronomy and art in Cosmos, regularly engage contemporary scientific writing. In Larson's case, that discussion centers on the books of Flammarion (see Clair 1999, 170-71). Critical reading of the writings of artists, critics, and historians is a standard part of art historical training, and the fields of literature and science, history of science, and science studies offer excellent models of sophisticated analysis of literary and scientific texts for art historians interested in developing this field further. ${ }^{41}$ Conversely,

\footnotetext{
${ }^{40}$ For artists and optics from the Renaissance to the end of the nineteenth century, see, e.g., Kemp 1990.

${ }^{41}$ See, e.g., Peterfreund 1990, Hess 1997, Galison 1997, Clarke 2001, Henry 2003.
} 
of course, art historians have much to share with scholars of science and culture who have become increasingly engaged in visual imagery. ${ }^{42}$

That art historians have engaged far more of the art-science field than simply the image-based comparisons Elkins cites is particularly clear in the case of Marcel Duchamp. In his studies of science Duchamp found inspiration for both the verbal form (i.e., his several hundred textual notes) and visual form of his masterwork The Bride Stripped Bare by Her Bachelors, Even (The Large Glass) of 1915-23, a nine-foot tall construction on two glass panels (fig. 1). Having taken a librarian's job in Paris in 1913, Duchamp mulled over large numbers of science books to invent the "playful physics" of the Large Glass, deriving material for the content of his scientific allegory of sexual quest as well as for the style of his notes and his precision-oriented execution of the Glass. Based on the theme of electromagnetic wave-borne communication between the biomechanical Bride above and the mechanical Bachelors below, the work's narrative draws inventively on such fields as X-rays, radioactivity, atomic theory, the kinetic theory of gases, and thermodynamics - as well as classical mechanics, chemistry, biology, meteorology, automobile technology, and four-dimensional geometry. ${ }^{43}$ Duchamp even adopted the persona of artist/engineer, disdaining the artist's medium of oil on canvas in favor of materials associated with the laboratory: he actually utilized glass, lead wire, lead foil, mirror silver, and dust, and he speculated on various acids, mica, and rust, among other substances. For Duchamp (in a view that could no longer be held today) science represented a model of pure objectivity and a transparent language free of metaphor. He would certainly have been surprised by the demonstrations by historians of science of the central role that metaphor and analogical thinking play in the activities of the scientist. ${ }^{44}$

Like Duchamp, Smithson responded to science on multiple levels beyond visual imagery. In the end, Smithson's engagement with science and mathematics had equally far-reaching consequences for his entropy-based art theory, his form language, and for the content and style of his art writing (see, e.g., Reynolds 2003). As the essays in this issue of Science in Context make clear, the art historical component of science studies is quite capable of addressing those "oblique references" to science about which Elkins worries (see, e.g., Parkinson's essay herein exploring the Surrealist response to quantum theory).

Following upon the Common Denominators symposium, a much larger, international conference, Einstein Meets Magritte, took place in Brussels in 1995, bringing together an interdisciplinary group of scholars to "reflect together on the deep nature of reality

\footnotetext{
${ }^{42}$ Beyond art historical scholarship in general and Elkins's specific analysis of non-art images, see, e.g., Kemp 1997, as well as certain of the essays in Jones and Galison 1998, Latour and Weibel 2002, and Daston 2004.

${ }^{43}$ See Henderson 1998, Henderson 1999; for Duchamp's response to X-rays in 1911-12, see Henderson 1988 and Henderson 1998, chap. 1. For Duchamp's notes, see Duchamp 1973, Duchamp 1983.

${ }^{44}$ See, e.g., Galison, “Judgment Against Objectivity," in Jones and Galison 1998; and Bono 1990.
} 

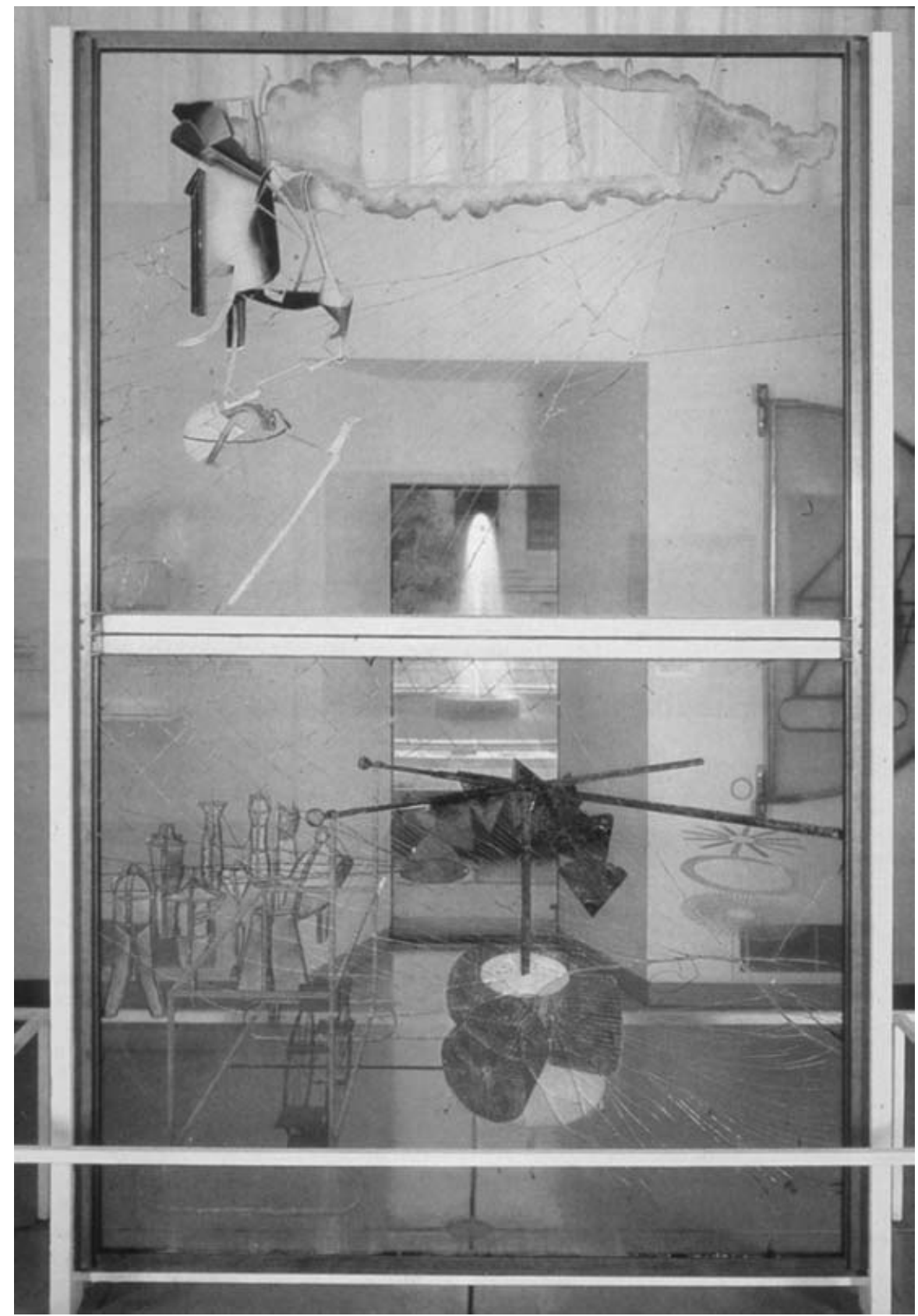

Fig. 1. Marcel Duchamp, The Bride Stripped Bare by Her Bachelors, Even, 1915-23, mixed media on glass. Philadelphia Museum of Art, Bequest of Katherine S. Dreier. (c) 2004 Artists Rights Society (ARS), New York/ADAGP, Paris/Succession Marcel Duchamp. Photo: Philadelphia Museum of Art. 
and the knowledge and skill humankind has gathered in this field" (Aerts 1999, vii). Published in eight volumes, the conference addressed a variety of themes (e.g., Science, Technology, and Social Change, Quantum Structures and the Nature of Reality, and The Evolution of Complexity), with only one book of proceedings devoted to Science and Art. The organizers chose Magritte - rather than Picasso - as the metaphorical figure for art in relation to Einstein's embodiment of science, and the conference sought to find "meaningful keys" at "the place where the two meet" (ibid., vii, xix). With its broad scope the conference produced a new round of meditations on intersections or commonalities between the activity of artists, musicians, and writers and of scientists (here extended to include social scientists) - with an emphasis on psychology and creativity in the Science and Art volume. The most historically oriented contribution addressing art in that collection is Edward Shanken's essay on the artist and educator Roy Ascott, who has based his "telematic" art and theory as well as his teaching on the principles of cybernetics and systems theory. ${ }^{45}$

Ascott's interest in new media technologies actually falls more accurately under the rubric of art and technology - a field that, apart from Goodyear's discussion of the Experiments in Art and Technology group in the 1960s as well as certain aspects of Kepes' Center for Advanced Studies in the Visual Arts at MIT, is not addressed specifically in this issue of Science in Context. ${ }^{46}$ Yet, as the Evolution of Complexity volume of Einstein Meets Magritte demonstrates, in the later twentieth-century systems theory and complexity theory came to play increasingly important roles across a range of scientific disciplines, particularly physics and biology, offering new possibilities for interdisciplinary discussions including art (see Heylighen, Bollen, and Riegler 1999). Indeed, Ilya Prigogine, who spoke on "Einstein and Magritte: A Study of Creativity" at the conference, came to link creativity directly to the uncertainty manifested in far-from-equilibrium systems (Prigogine 1999; see also Prigogine 2001).

To conclude this overview of work in the field of modern art/science studies, four contributions published in 2002 serve to demonstrate the range of approaches in use at present. These are Exploring the Invisible: Art, Science, and the Spiritual by Lynn Gamwell, two collections of essays based on symposia - Experimental Cultures: Configurations Between Science, Art, and Technology, 1830-1950 and From Energy to Information:

\footnotetext{
45 Shanken's essay is “Technology and Intuition: A Love Story? Roy Ascott's Telematic Embrace”; see Aerts et al. 1999, 141-56.

${ }^{46}$ Art and technology has another historiography and is growing rapidly as a field because of the interest in new media on the part of many artists. Jonathan Benthall's 1972 paperback Science and Technology in Art Today stands as an early survey of this subject and, despite its title, focuses primarily on technology with a far more limited consideration of science (see, e.g., chaps. 6, 8). The same could be said of Jack Burnham's more ambitious 1968 book Beyond Modern Sculpture: The Effects of Science and Technology on the Sculpture of This Century, which surveys the history of modern sculpture in relation to technology (especially the developing field of cybernetics) and, to a lesser degree, science. The journal Leonardo has played and continues to play an important role in chronicling developments in art and technology. For a sampling of recent work, see, e.g., the volume Art@Science, a collection of essays by media artists and "media scientists" (Sommerer and Mignonneau 1998) as well as Wilson 2002.
} 
Representation in Science and Technology, Art, and Literature - and the monumental book published in conjunction with the exhibition Iconoclash: Beyond the Image Wars in Science, Religion, and Art.

Gamwell's Exploring the Invisible is lavishly illustrated with colorplates and provides the most useful extant survey of developments in science and artists' responses to them from German Romanticism to the late twentieth century. A museum director who has organized a number of art/science exhibitions, Gamwell positions her images in a wide-ranging narrative that traverses the space between German idealist philosophy's vision of unity and the "disunity" she laments in the postmodern era (Gamwell 2002, 281). As might be expected with any book that spans two hundred years, many topics must be dealt with rather cursorily, and, although she draws on the research of many other art historians, there is no evidence of the impact of science studies in her approach. Gamwell's previous work in the history of psychology and her deliberate focus on Germany rather than France account for the volume's most original elements. The most traditional of this group of four, Gamwell's book, nonetheless, serves as an effective - and strikingly beautiful - introduction to the topic of art and science.

Although published in 2002, From Energy to Information grew out of an interdisciplinary symposium at the University of Texas organized by Bruce Clarke and myself in 1997. The conference brought together trios of historians of science, literature, and art around five semi-chronological themes: The Cultures of Thermodynamics; Ether and Electromagnetism: Capturing the Invisible; Traces and Inscription: Diagraming Forces; Representing Information [Cybernetics]; and Virtual Spaces/Virtual Bodies. This structure, basically replicated in the book, was intended to give scholars in the humanities and the sciences a sampling of the historical contexts and theoretical connections among scientific ideas, technological developments, and art and literature in the later nineteenth and twentieth centuries. Rethinking representation across disciplinary boundaries raised significant issues, and in this context anthropologist Bruno Latour's conception of the "inscriptions" made in the scientific laboratory proved to be a useful means of thinking about mark-making in science and art alike (Henderson and Clarke 2002, 6-7). More generally, essays in the volume highlight the prevalence of the theme of energy within modern art and literature and the analogous role of its counterpart, information, in the later twentieth century.

Latour himself was a participant in the Experimental Cultures: Configurations Between Science, Art, and Technology, 1830-1950, a conference at the Max Planck Institute for the History of Science in Berlin in 2001. This event was part of an ongoing project at the MPIWG centered on the life sciences in the nineteenth century and the first half of the twentieth century. Following Foucault and the interest of the Annales school of French historians in the longue durée, the project seeks to discover a "knowledge landscape of the life sciences" through this period by exploring "experimental cultures" or "cultures that generate difference" rather than bringing closure. It is at this level with its basic reconsideration of what it is to do science (e.g., "skills, knowledge spaces, model organisms, epistemic objects, ways of doing, and instruments") - that the 
conference looked across fields to the arts to find similar cultures of experimentation (MPI 2002, 11-12). Peter Geimer, whose essay on "Picturing the Impossible: On Blanks in Nineteenth-Century Artistic and Scientific Pictures" opens the current issue of Science in Context, focused on physiologist Sigmund Exner's exploration of artists' depictions of the human body in flight in "Physiology of the Impossible: Exner Meets Mythology" (ibid.,13-22).

Finally, the innovative, large-scale exhibition Iconoclash: Beyond the Image Wars in Science, Religion, and Art was co-organized by Latour and by Peter Weibel, Director of the Zentrum für Kunst und Medientechnologie, Karlsruhe. In striking contrast to art/science exhibitions of the past, Iconoclash was centered on a conceptual question: why and how have scientific, artistic, and religious images provoked such passionate responses - either negative or positive - in viewers? The images addressed range from ancient to contemporary, and essays by over sixty authors treat a wide variety of topics related to the exhibition's central theme. History and theory come together in this volume, which also includes essays by Science in Context contributor Peter Geimer as well as Caroline Jones, Peter Galison, and several of the authors also included in their Picturing Science, Producing Art volume. Galison's essay, "Images Scatter into Data, Data Gather into Images," tracks the oscillating attitudes toward visual images versus pure logic in the sciences since the nineteenth century, concluding that in the digital era the "image to non-image to image" exchange occurs incessantly. Looking to art, Galison then proposes that rather than the abstraction that has sometimes been cited as one of the commonalities of the two fields, it is the "shifting historical realizations of concrete abstraction or abstract concreteness that the two fields share (see Latour and Weibel 2002, 322-23). ${ }^{47}$

This issue of Science in Context will stand as another contribution to the early twenty-first century scholarship on the interaction of art and science. Both Geimer's and Botar's texts interrogate the status of photography in relation to art and science. Geimer's "Picturing the Imperceptible" essay complicates conventional understanding of "scientific photography" by pointing up the crucial role of imagination and intervention on the part of photographers such as A. M. Worthington in presenting ostensibly automatic, objective recording of splashes. While Geimer comments as well on the painter Edouard Manet's "quasi-photographic" reference to the imperceptible in his Execution of the Emperor Maximilian, Botar explores the integration of artistic

\footnotetext{
${ }^{47}$ Lorraine Daston's recently published essay collection, Things That Talk: Object Lessons from Art and Science, represents yet another approach to interdisciplinary work on art and science (Daston 2004). The product of a "working group" of historians of science and of art at the Max Planck Institute for the History of Science in Berlin during 2001-2002, including Galison and Jones and several other of the contributors to their 1998 volume, each essay focuses on a single object in the scholar's field to understand how "what things are made of and how they are made shape what they can mean" (ibid., dustjacket). These historically grounded studies, which draw also on philosophy and anthropology, offer important methodological lessons for both the history of science and the history of art.
} 
and scientific representation in photography in the context of Moholy-Nagy's "new vision" for art, grounded in the discourse of biocentrism in Weimer Germany.

The other essays in the issue - by Larson, Parkinson, Petersen, and Goodyear all investigate particular cultural moments in which artists responded to new scientific ideas and images - as well as, in Goodyear's case, new technologies. Larson examines Symbolist Odilon Redon's incorporation of the invisible world of microbes into his drawings and lithographs and establishes the context for this interest in the work of Pasteur, the germ theory of disease, and contemporary concern about hygiene. Surrealist artists were deeply interested in Symbolists like Redon, but by the 1930s Surrealism had found a new science in addition to Einsteinian Relativity Theory: popularized quantum mechanics. In contrast to the standard histories of Surrealism, which focus on psychoanalysis, Parkinson's essay carefully tracks the diffusion of quantum mechanics in French sources and establishes the way in which the anomalies of quantum physics suited perfectly the Surrealist project, particularly in the work of the painters Wolfgang Paalen and Roberto Matta. Of modern artists involved with science in the first decades of the century, the major omission in this Science in Context issue is the Russian avant-garde, including Kazimir Malevich. As in the case of Duchamp, however, there is considerable literature on this subject (see, e.g., Douglas 1984; Douglas 1994; Looper 1995; Galerie Gmurzynska 1999; State Russian Museum 2000; Douglas 2002). ${ }^{48}$

Petersen's essay moves to mid-century and explores the response of artists to the atomic bomb, which had itself occasioned much of the early writing on art and science. His pioneering work on the Italian artists of the Spatial Art and Nuclear Art movements, who sought to manifest in paint the hidden energy of the atom, illuminates a vital episode in the much-understudied area of postwar European art. Finally, Goodyear investigates the rise of interest in science and technology by artists as well as public officials in the wake of the Russian launch of Sputnik in 1957. Her study centers on the activities of Kepes and Billy Klüver (founder of Experiments in Art and Technology) and, hence, provides a denouement for the vision of art, science, and technology that Kepes developed in the early twentieth century, in relation to the Bauhaus-based ideals of his mentor Moholy-Nagy. A preoccupation with the invisible aspects of nature remained a vital theme for Kepes to the end, just as it had been for Worthington and his splashes, Redon and microbes, Moholy's "new vision” of photography (including

\footnotetext{
${ }^{48}$ Duchamp and Malevich shared an interest in four-dimensional space, although in contrast to Duchamp's geometrical orientation Malevich embraced the mystical hyperspace philosophy of P. D. Ouspensky (see Henderson 1983, chaps. 3, 5). Malevich's scientific interests ranged from physiology to electromagnetism, energetics, and thermodynamics, which came to play a role in the theory of the abstract Suprematist style he inaugurated in 1915 (see Douglas 2002, 385, n. 24). In post-revolutionary Russia Malevich not only developed a theory of art's evolution based on the tuberculosis bacilli (Looper 1995), but, as a teacher, sought to produce "a new personnel of scientific artists" (State Russian Museum 2000, 7). Malevich's longtime colleague Mikhail Matiushin headed the Dept. of Organic Culture at the State Institute for Art Culture (GINKhUK) in the 1920s and focused on the study of perception and its expansion (Douglas 1984; Galerie Gmurzynska 1999).
} 
the X-ray), the Surrealists and quantum phenomena, and the Italian artists in the 1950s who committed themselves to atomic and nuclear art.

\section{Cubism, Futurism, and Ether Physics in the Early Twentieth Century}

Returning to the question of Cubism and science leads us to another key moment in the history of modernism's engagement with the invisible and imperceptible, which forms a leitmotif within this issue of Science in Context. In order to determine the parameters of "what it was possible to imagine" (Harrison 1993) for an artist like Picasso in the pre-World War I era, we need to investigate the visual evidence of his Cubist works (e.g., the Portrait of Kahnweiler of 1910 [fig. 2]) within the cultural field of avant-garde art writing, popular scientific literature, and even occult sources in this period. Unfortunately, Picasso himself remains an elusive subject, a painter's painter who wrote no statements of his artistic ideas in this period - in contrast to the Salon Cubists Albert Gleizes and Jean Metzinger, Duchamp, or the Italian Futurists, such as Umberto Boccioni (see his 1913 drawing Muscular Dynamism on the cover of this issue). ${ }^{49}$ Like Duchamp, whose extensive notes for the Large Glass provide a useful guide to science as popularly known in prewar Paris, Boccioni was actively engaged with contemporary science. As he queried in a diary entry of 1907, "How, where, when can I study all that chemistry and physics?" (Coen 1988, 257). ${ }^{50}$ Thus, chronicling Boccioni's visual and verbal responses to contemporary science serves as a useful counterpoint to an examination of Picasso's Cubism, given the considerable artistic and literary exchange between Paris and Milan. ${ }^{51}$

For Picasso the case will necessarily be more circumstantial. Yet an artist hardly needed to have had the specific interest in science of Boccioni or Duchamp, since the exhilarating new ideas issuing from contemporary science were readily available in popular journals, newspapers, and books as well as responses to these phenomena in avant-garde literature. ${ }^{52}$ In addition, the presence of the erudite poet Guillaume Apollinaire in Picasso's circle and the record of his library provide important clues to ideas that may have been present within Picasso's milieu, which also included the poet Max Jacob, the poet and critic André Salmon, and the salon of Gertrude Stein.

\footnotetext{
${ }^{49}$ On the interests of the Salon or "Puteaux" Cubists, see, e.g., Henderson 1983, Antliff and Leighten 2001. Metzinger, initially a member of Picasso's circle, formed a bridge between the two groups. On Duchamp's relation to the Salon Cubists, see Henderson 1998. For Boccioni, see, e.g. Coen 1988.

${ }^{50}$ For Duchamp's interest in science, see again n. 43 and the related text above.

51 On the interconnections, see, e.g., Martin 1969, in which Futurism's founder F. T. Marinetti is described as "practically commut[ing]" between Milan and Paris. Boccioni’s fellow Futurist Gino Severini lived in Paris from 1906 onward and married the daughter of French poet Paul Fort, around whom the avant-garde gathered. See Antliff and Leighten 2001, 20-22. Boccioni and his fellow painters visited Paris in October 1911 and met both Picasso and the Salon Cubist circle.

${ }^{52}$ For the literary response to new developments in science and technology, see, e.g., Henderson 1998, 98-100.
} 


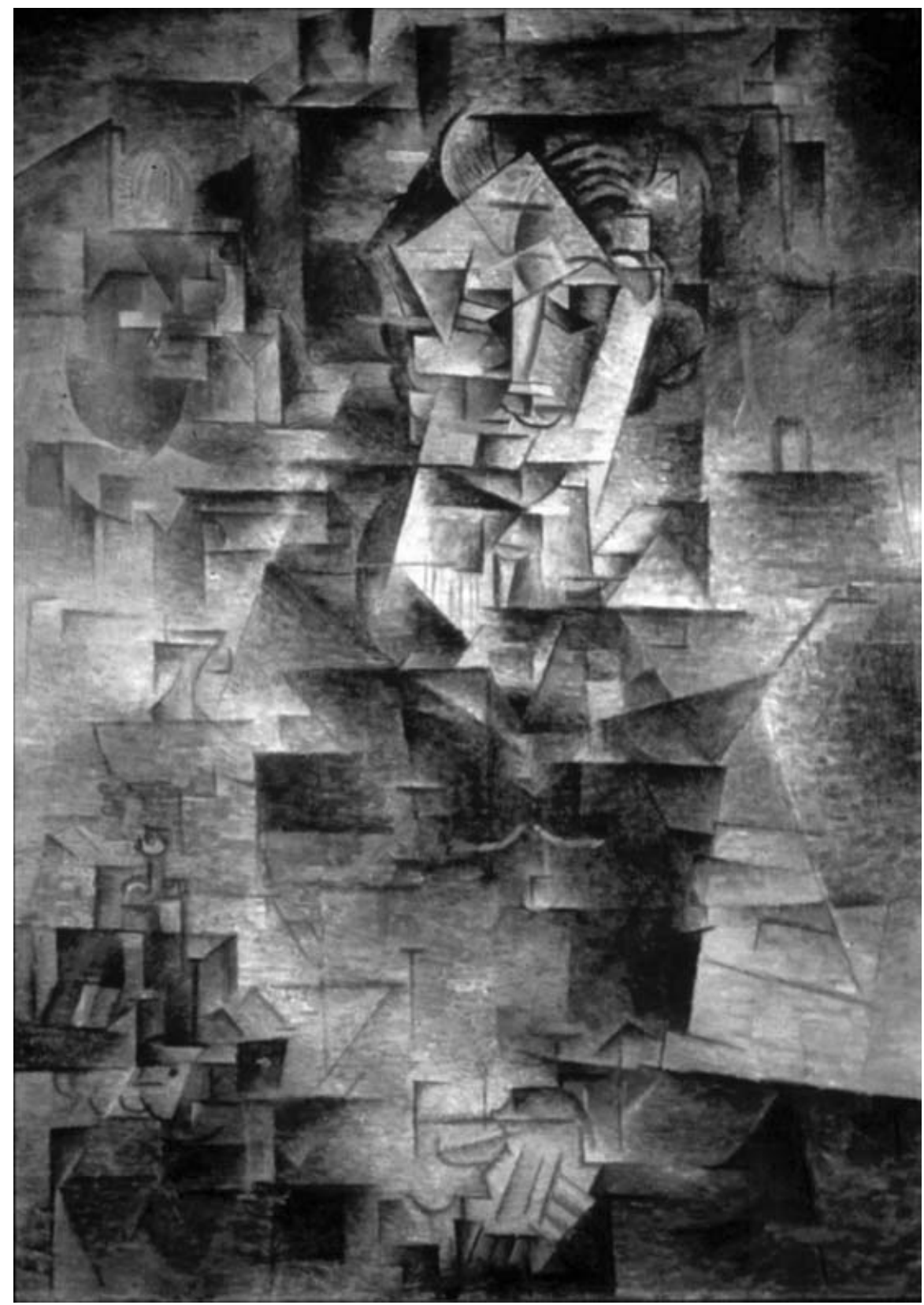

Fig. 2. Pablo Picasso, Portrait of Daniel-Henry Kahnweiler, 1910, oil on canvas. Art Institute of Chicago, Gift of Mrs. Gilbert W. Chapman in memory of Charles B. Goodspeed. (C) 2004 Estate of Pablo Picasso/Artists Rights Society (ARS), New York. Photo: Art Institute of Chicago. 
Before investigating Picasso, we need to de-familiarize his Analytical Cubist works such as the Portrait of Kahnweiler, which have come to look so natural to us in the last fifty years, hanging on the walls of collections of modern art. Since mid-century we have tended to see Cubist painting through the formalist art historical explanations of its evolution as a logical, internal stylistic development, resulting from the lessons Picasso and his collaborator Georges Braque learned from the art of Paul Cézanne and African art. ${ }^{53}$ Hence, from Cézanne came the initial geometrical orientation and denial of onepoint perspective and from African art, the powerfully simplified forms and, ultimately, the conceptual sign language that enabled Picasso to communicate information about a sitter in the same way a caricaturist distills a subject's key characteristics. Yet, while the stylistic explanation is convincing for early Cubist painting, by later 1909 or 1910, such radical changes occur that artistic sources alone are no longer adequate. More recent scholarship has gone a considerable way toward recovering Cubism's larger cultural context, including the fourth dimension, the philosophy of Henri Bergson, and contemporary politics, but there are still basic questions posed by paintings such as the Portrait of Kahnweiler. Why would Picasso and Braque so stubbornly deny the solidity and boundaries of forms, causing their sitters to dissolve into the surrounding space? The two painters always considered themselves realist painters, with Picasso explaining later, "I paint objects as I think them, not as I see them" (Gómez de la Serna 1929, 100). What can Picasso have been thinking or imagining about the nature of reality?

Over two decades before the public in France first heard of Einstein and Relativity Theory, the decade of the 1890 s witnessed a series of scientific discoveries that successively challenged conventional notions of matter and space. These widely discussed developments included Wilhelm Conrad Röntgen's discovery of the X-ray in 1895, Henri Becquerel's discovery of radioactivity in 1896 (extended by the subsequent work of Marie and Pierre Curie as well as Ernest Rutherford), J. J. Thomson's identification of the electron in 1897, and the subsequent establishment of wireless telegraphy based on the electromagnetic waves Heinrich Hertz had identified in $1888 .{ }^{54}$ The existence of invisible realms just beyond the reach of the human eye was no longer a matter of mystical or philosophical speculation; it had been established empirically by science. Madame Curie asserted in regard to radioactivity in 1904, "Once more we are forced to recognize how limited is our direct perception of the world around us" (Curie 1904, 461).

Röntgen's discovery of the X-ray caused the greatest popular scientific sensation before the explosion of the atomic bomb in 1945 (Badash 1979, 9). Rendering matter transparent, X-rays made previously invisible forms visible. Even more importantly,

\footnotetext{
${ }^{53}$ For that narrative, which was promulgated in Museum of Modern Art publications by Alfred Barr and William Rubin, see, e.g., Fry 1966. For a thorough, step-by-step tracking of the evolution of Picasso's Cubist style, see, e.g., Karmel 2003.

${ }^{54}$ For these developments, see, e.g., Keller 1983, Kragh 1999; for their popularization, see Henderson 1998.
} 
however, the X-ray definitively demonstrated the inadequacy of the human eye, which detects only a small fraction (i.e., visible light) of the much larger spectrum of vibrating electromagnetic waves then being defined. ${ }^{55}$ As the astronomer Flammarion argued of X-rays in his 1900 book L'Inconnu, " $[\mathrm{I}] \mathrm{t}$ is unscientific to assert that realities are stopped by the limits of our knowledge and observation" (Flammarion 1901,14). On a practical level, X-rays were quickly adopted in medical practice, and photography journals touted X-ray photography as the natural extension of the amateur photographer's activity. And the massive amount of popular literature on the subject - including articles, books, songs, cartoons, poems, and cinema - kept X-rays and their subsequent development in the news well into the first decade of the new century (see Glasser 1934, chap. 6; Knight 1986; Henderson 1988).

$\mathrm{X}$-rays offered a radically new way of seeing, breaking down the barrier that the skin had always represented between outer and inner. That same transparency and fluidity are evident in Picasso's portrait of his dealer Daniel-Henry Kahnweiler, a shift the sitter himself described around 1915 as "pierc[ing] the closed form" or "skin" (Kahnweiler 1949, 10). Here was a new kind of light that allowed a painter to go beyond the preoccupation of earlier artists with surface appearances. Kahnweiler also noted that Picasso considered traditional modeling with visible light and shade to be a dishonest “illusion” (Kahnweiler 1949, 11; Karmel 2003, 12). Beyond the ubiquity of the X-ray in popular culture, Picasso was an amateur photographer and would have encountered the advocacy of the new X-rays as "photography of the invisible" in photography journals. Further, as John Richardson has documented, Picasso's companion, Fernande Olivier, was X-rayed in a hospital in January 1910. And in 1917 Picasso queried in one of his sketchbooks, "Has anyone put a prism in front of X-ray light?" (Richardson 1996, 158). All of this is not to suggest that Picasso's images derive from X-ray photographs, but rather that Cubist painting employs the general model of penetrating vision as well as the characteristics of transparency and fluidity suggested in X-ray images. ${ }^{56}$

Although, in contrast to Picasso's static sitter, Boccioni's Muscular Dynamism depicts a figure in motion, the Futurist's drawings and paintings of this period exhibit a similar fluid relationship of figure and space. It was Boccioni who had made the first published mention of X-rays in relation to avant-garde painting, declaring in the 1910 "Technical Manifesto of Futurist Painting": "Who can still believe in the opacity of bodies ...? Why should we forget in our creations the doubled power of our sight, capable of giving results analogous to the X-rays?” (Boccioni 1973, 28). Subsequently, he asserted in 1911, "What needs to be painted is not the visible but what has heretofore been

\footnotetext{
${ }^{55}$ Although Röntgen and others suspected that the new rays were electromagnetic waves akin to visible light and Hertzian waves, the wave-nature of X-rays would be confirmed experimentally only in 1912. Popularizations of X-rays often included tables or diagrams charting the ranges of known and unknown invisible radiations surrounding the narrow band of visible light perceptible to the human eye (e.g., Snyder 1903, 119).

${ }^{56}$ For theorists of Cubism such as Gleizes and Metzinger, who had been close to Picasso in 1909-10, such profound, expanded seeing was a central feature of the new style (see, e.g., Henderson 1988, 335-36).
} 
held to be invisible, that is, what the clairvoyant painter sees" (Coen 1988, 239). Given the Futurists' connections to activities in Paris, Boccioni's comments testify to the international currency of the new focus on the invisible as well as occultism, in which Boccioni was deeply interested. ${ }^{57}$

The interpenetration of matter and space in the works of both Picasso and Boccioni would have been encouraged equally in this period by popular fascination with radioactivity. With the Curies' isolation of two new radioactive elements, polonium and radium, in 1898 and Ernest Rutherford's subsequent formulation of the theory of radioactive decay in 1902-3, radioactivity captured the attention of the general public (Badash 1979). Radioactive substances produced yet another kind of invisible emissions - alpha, beta, and gamma "rays" (actually particles in the case of the alpha and beta emissions) - and, in the process, actually changed their chemical composition, releasing energy. In contrast to the traditional image of matter as stable and constant, the continuous emission of particles by radioactive substances suggested a vibrating realm of atomic matter in the process of transformation. In his best-selling books, such as L'Evolution de la matière (1905), scientific popularizer Gustave Le Bon argued that all substances were radioactive and that matter was only "a stable form of intra-atomic energy" in the gradual process of decaying back into the ether of space around it (Le Bon 1905, 9; see also Le Bon 1906). ${ }^{58}$ Le Bon was a friend of the philosopher Henri Bergson, whose import for the Cubists and Boccioni has been well established. Also, certain of Bergson's views stand as counterparts to Le Bon's popularization of universal radioactivity (see, e.g., Antliff 1993; Antliff and Leighten 2001, 80-93; Petrie 1974). In books such as Matter and Memory of 1896 and Creative Evolution of 1907, Bergson argued that the essence of reality was flux and that "all division of matter into independent bodies with absolutely determined outlines is an artificial division" (Bergson 1988, 196).

Anyone could observe the phenomena of radioactivity at home in the popular parlor toy, the spinthariscope, invented by Sir William Crookes in 1903. Holding this tiny cylindrical instrument fitted with a magnifying lens to the eye, a viewer could see the flashes of light produced when alpha particles from a speck of radium struck the zinc-sulphide screen within. In Picasso's Portrait of Kahnweiler figure and ground are unified by a shimmering, vibratory texture of brick-like Neo-Impressionist brushstrokes that likewise suggests atoms of matter disassociating into the surrounding space, itself already filled with such particulate emissions. Such images likewise deny the "independent bodies" Bergson had rejected in favor of reality as continuity and flux.

\footnotetext{
${ }^{57}$ On the Futurists' interest in the occult, particularly spirit photography, see Celant 1981.

${ }^{58}$ Lodge and Rutherford also mentioned the possibility of universal radioactivity in their popular writings (Lodge 1904, 386; Rutherford 1904, 284). On Le Bon, see Nye 1974. In a prescient article (Mitchell 1977), Timothy Mitchell pointed to Le Bon's possible significance for Cubism; however, without reconstructing the larger popular scientific context for Le Bon himself, this essay had little impact on Cubist scholarship at the time.
} 
Boccioni's paintings of this period, such as his depiction of his mother entitled Matter of 1912 (Giovanni Mattioli Collection, Milan), are likewise executed in a tapestry of discrete brushstrokes with which he deliberately sought to convey the dematerialization of matter. ${ }^{59}$ In his writings Boccioni spoke of "the electric theory of matter, according to which matter is only energy," a contemporary theory closely associated with the ether of space, which was also central to Boccioni's aesthetic (Boccioni 1975, 105).

Picasso need not have read Le Bon's best-selling books himself. His close compatriot Apollinaire owned a 1908 imprint of Le Bon's L'Evolution de la matière as well as Commandant Darget's book on how to photograph "fluido-magnetic" bodily emanations, such as the "Rayons V (Vitaux)," one of the numerous varieties of emissions and rays thought to have been discovered in the wake of X-rays. ${ }^{60}$ In the context of contemporary views of photography as a revealer of the invisible, Picasso seems to have been fascinated by the intrusion into his own photographs of "noise" suggestive of invisible phenomena. ${ }^{61}$ Like Boccioni, Apollinaire was deeply interested in occultism, and he owned a number of books dedicated personally to him by occultist Gaston Danville, including the latter's 1908 Magnétisme et spiritisme (Boudar and Décaudin 1983, 52). In fact, occult sources served in this period as an important means for the popularization of the new physics, with texts on the practice of Magnetism or on other sort of emissions often drawing on the latest developments in the physics of electromagnetism. ${ }^{62}$ Given the Curies' prominence as French cultural luminaries and with Apollinaire close at hand, Picasso could hardly have been unaware of radioactivity's fundamental reorientation of basic conceptions of matter as well as its occult interpretations.

Along with radioactivity and Le Bon's talk of matter dematerializing into the ether, the recently discovered Hertzian waves of wireless telegraphy (as well as X-rays) focused popular attention on the invisible, impalpable ether of space. Space was not thought of as empty in this period, and the terms space and ether of space are often synonymous in the written record. The longstanding concept of a world-filling "aether" had returned to physics in the 1820s with Augustin Jean Fresnel's positing of a "luminiferous ether" as the necessary medium for the propagation of light waves. By the 1860s James Clerk Maxwell and William Thomson (Lord Kelvin) had concluded that a material ether must also be the source of and vehicle for electromagnetic fields. ${ }^{63}$ Early conceptions of the imponderable ether ranged from a thin elastic jelly to a swirling fluid, and Kelvin

\footnotetext{
${ }^{59}$ For Boccioni's Matter in scientific and occult context, see Henderson 2002.

${ }^{60}$ On the rage for various new rays, see, e.g., Kragh 1999, 34-37. For Apollinaire's library holdings, see Boudar and Décaudin 1983. On Apollinaire and the occult, see Hicken 2002.

${ }^{61}$ See Baldassari 1997, 87, figs. 83, 84, 109. See also, e.g., Mareschal 1897, and Geimer 2000.

${ }^{62}$ For example, Albert de Rochas added fifteen appendices to his 1895 L'Extériorisation de la sensibilité, including recent writings by Lodge and Edwin Houston (for Rochas' book, see Houston [1895] 1909 in the list of References); see also Henderson 1998, 101-2; or Henderson 2002, 140-42).

${ }^{63}$ On the ether, see, e.g., Cantor and Hodge 1981, Harman 1982, Hunt 2002. For an excellent discussion of the ether as a fictional construct rooted in the commitment of nineteenth-century physicists to a model of
} 
suggested that atoms might well be whirling vortices in the ether, akin to smoke rings. In the later nineteenth and early twentieth century, additional new functions were proposed for the ether, including its possible role as the source of all matter, as in the "electric theory of matter" propounded by Joseph Larmor and Sir Oliver Lodge and embraced in the writings of Boccioni and in Wassily Kandinsky's 1911 Über das Geistige in der Kunst (see, e.g., Lodge 1904; Kandinsky 1973, 40).

In order to transmit vibrating electromagnetic waves, including light, the mysterious ether required the rigidity of an elastic solid; at the same time, it must allow the free motion of bodies through it and be rarefied enough to flow through the interstices of even the densest matter. Le Bon noted the difficulty of discussing this "phenomena without analogy" (Le Bon 1905, 88); not surprisingly, the writing on the ether by both scientists and popularizers is filled with metaphor. The passage of the immaterial ether through matter was compared to water flowing through a sieve (Houston 1892, 489; Houston 1909, 232); yet the ether as the very source of matter made this relationship more complex. As science writer Robert Kennedy Duncan declared of this "vast circumambient medium" in 1905: "Not only through interstellar spaces, but through the world also, in all its manifold complexity, through our own bodies; all lie not only encompassed in it but soaking in it as a sponge lies soaked in water." Raising a basic question repeatedly encountered in popular literature in this period, Duncan declared, "How much we ourselves are matter and how much ether is, in these days, a very moot question" (Duncan 1905, 5; see also, e.g., De Launay 1908). The same year Le Bon in L'Evolution de la matière emphasized the ether's elemental role in nature:

The greater part of physical phenomena - light, heat, radiant electricity, etc., are considered to have their seat in the ether.... All the theoretical researches formulated on the constitution of atoms lead to the supposition that it forms the material from which they are made. Although the inmost nature of the ether is hardly suspected, its existence has forced itself upon us long since, and appears to be more assured than that of matter itself.... Its role has become of capital importance, and has not ceased to increase with the progress of physics. The majority of phenomena would be inexplicable without it. (Le Bon 1905, 88-89) ${ }^{64}$

Historians of culture regularly treat Einstein's 1905 Special Theory of Relativity (if not the 1887 Michelson-Morley experiment's failure to detect an "ether wind" resulting from the earth's motion) as the death knell of the ether. However, not only did the general public not hear of Einstein's theories until 1919, the question of the existence of the ether was hotly debated among scientists skeptical of Einstein's theories during the 1910s and 1920s, with passionate defenses of the ether being made in scientific and

continuity in nature, see Benson 1984. The ether was discussed in a variety of French popular sources in addition to Le Bon's writings; see, e.g., De Launay 1908.

${ }^{64}$ Le Bon's book was still popular in 1911, when a translation was published in London and New York; see Le Bon 1911, 87-88. 
popular literature, including in France. ${ }^{65}$ Reflecting the mood of the ether's adherents, Sir J. J. Thomson declared in his Presidential Address before the British Association for the Advancement of Science in 1909, "The ether is not a fantastic creation of the speculative philosopher; it is as essential to us as the air we breathe. .. The study of this all-pervading substance is perhaps the most fascinating duty of the physicist" (Thomson 1910, 15). Lodge certainly took that position, and his own BAAS Presidential Address, published as Continuity in 1913, along with his 1909 The Ether of Space and countless popular articles, kept the ether in the spotlight in England and the United States, as well as in France. In Einstein's Germany the ether also continued to be championed in the 1910s by scientists such as Gustav Mie, for whose electromagnetic theory of matter it was central. ${ }^{66}$ Even with the ultimate scientific triumph of Relativity Theory sans ether, the concept possessed such a powerful grip on the cultural imagination that it lasted well into the 1920 s and beyond. ${ }^{67}$

In the late nineteenth and early twentieth century the ether was the ultimate sign of continuity and signified a realm of continuous cohesion and diffusion, materialization and dematerialization, coursed through by forces and vibrating waves. Two later statements by Picassso are remarkably suggestive of this insubstantial realm. Speaking of his paintings of the period 1910-1912 he told curator William Rubin, "It's not a reality you can take in your hand. It's more like perfume - in front of you, behind you, to the sides. The scent is everywhere, but you don't quite know where it comes from" (Rubin 1972, 72). Some years earlier he had described his portrait of Kahnweiler to Françoise Gilot in similar terms: "In its original form it looked to me as though it were about to go up in smoke. But when I paint smoke, I want you to be able to drive a nail into it. So I added the attributes - a suggestion of the eyes, the wave in the hair, an ear lobe, the clasped hands - and now you can" (Gilot and Lake 1964, 73). Did Picasso resort to such language because the ether was no longer in common parlance as it had been? Significantly, the association of the ether with smells such as perfume appears in a contemporary text, Emile Durkheim's The Elementary Forms of

\footnotetext{
${ }^{65}$ In addition to Lodge, the ether's most stalwart defender (e.g., Lodge 1920), see, e.g., Magie 1912, 290-91; and Marshall 1914, 446. Although Paul Langevin championed Einstein in France, advocacy of the ether there continued into the 1920s; see, e.g., Glick 1987, 136-44.

${ }^{66}$ Lodge's publications were followed in France (see, e.g., De Launay 1908, 392). On Mie, see Kragh 1999 , 117-19; and Corry 1999. Einstein himself found it necessary to define a "new ether" in his 1920 lecture "Ether and the Theory of Relativity." There he posited a "gravitational ether" without mechanical properties that "determine[d] the metrical relations in the space-time continuum" and could be identified with space itself. Einstein concluded with a statement subsequently quoted gleefully by the ether's proponents: "We may say that according to the general theory of relativity space is endowed with physical qualities; in this sense, therefore, there exists an ether. According to the general theory of relativity space without ether is unthinkable" (Einstein 1922, 20, 22-23).

${ }^{67}$ On literary responses to the ether, including that of D. H. Lawrence, see Clarke 2001, chap. 7. Leon Theremin christened his electronic musical instrument, premiered in 1920 and later termed a theremin, an "etherphone." On the numerous ether references that surrounded Theremin and his "ether wave music" - as well as radio, see Glinsky 2000.
} 
the Religious Life of 1912. In discussing the powers of collective representations to take on "properties that do not exist in them," Durkheim concedes that sensations of smell, taste, and sight "do express the properties of particular material or movements of the ether that really do have their origin in the bodies we perceive as being fragrant, tasty, or colorful" (Durkheim 1995, 229).

The ether is probably the major lacuna in scholars' understanding of the early twentieth century worldview - both scientific and occult - and, hence, its importance for modernism in general. We need to be alert to its presence in writing of the period, although as in the Durkheim example, it may simply appear as a commonplace reference. Seen as both an ancient and a modern concept, the ether figured prominently in occultism, and there achieved another kind of ubiquity. Apollinaire himself responded to Theosophist Madame Blavatsky's writing on the subject, echoing her in a 1915 letter: "Is not every part of the material universe - including the immaterial ether - a microcosm?" (quoted in Henderson 1986, 228).

The ether, along with Bergson's philosophy, figures in Apollinaire's fellow poet Jules Romains's theory of collective consciousness, which he termed Unanimism (see, e.g., Martin 1969; Antliff and Leighten 2001, 93-95). In his 1908 prose poem La Vie Unanime Romains celebrated the experience of immersion in a vibrating, energyfilled ether on a Paris street. The section of the poem titled "Dynamism," which also speaks of "rays that cannot be seen to vibrate," begins with the epigram "The present vibrates" and includes this passage: "The current/crowd, which struggles to pass through/And gets hooked on the hedges of molecules, bleeds. The ripples of ether part, [vibrating] with excitement" (Romains [1913], 79). The Salon Cubists circle was close to Romains, and it has been argued that the presence of smoke in their paintings was an allusion to Unanimism's celebration of urban experience, an idea that takes on new significance in relation to the ether (Sund 1984).

The ether was also at the heart of Boccioni's artistic theory. At the conclusion of his 1914 treatise Pittura scultura futuriste Boccioni reveals the formative role of the ether as ultimate sign of continuity in his conception of the 1913 sculpture Unique Forms of Continuity in Space (fig. 3), for which Muscular Dynamism is a study (Henderson 2002, 133-38). Believing that "solid bodies are only atmosphere condensed," Boccioni here creates a remarkable image of successive muscular displacements that deny the boundaries of the body and leave traces or imprints on the surrounding ether, suggesting "ether drag." In his treatise Boccioni specifically equates the "materialization of the ethereal fluid, the imponderable" with "the unique form of continuity in space" (Boccioni 1975, 104). In the end, Muscular Dynamism, with its continuous interpenetration of figure and space, may be even more successful as a representation of the fluid continuity suggested by the ether (cover illustration).

Boccioni also related Unique Forms of Continuity in Space to the spatial fourth dimension. He appears to have thought of the sculpture alternatively as a fourdimensional entity passing through three-dimensional space and registering a succession of different appearances - "a continuous projection of forces and forms intuited in their 


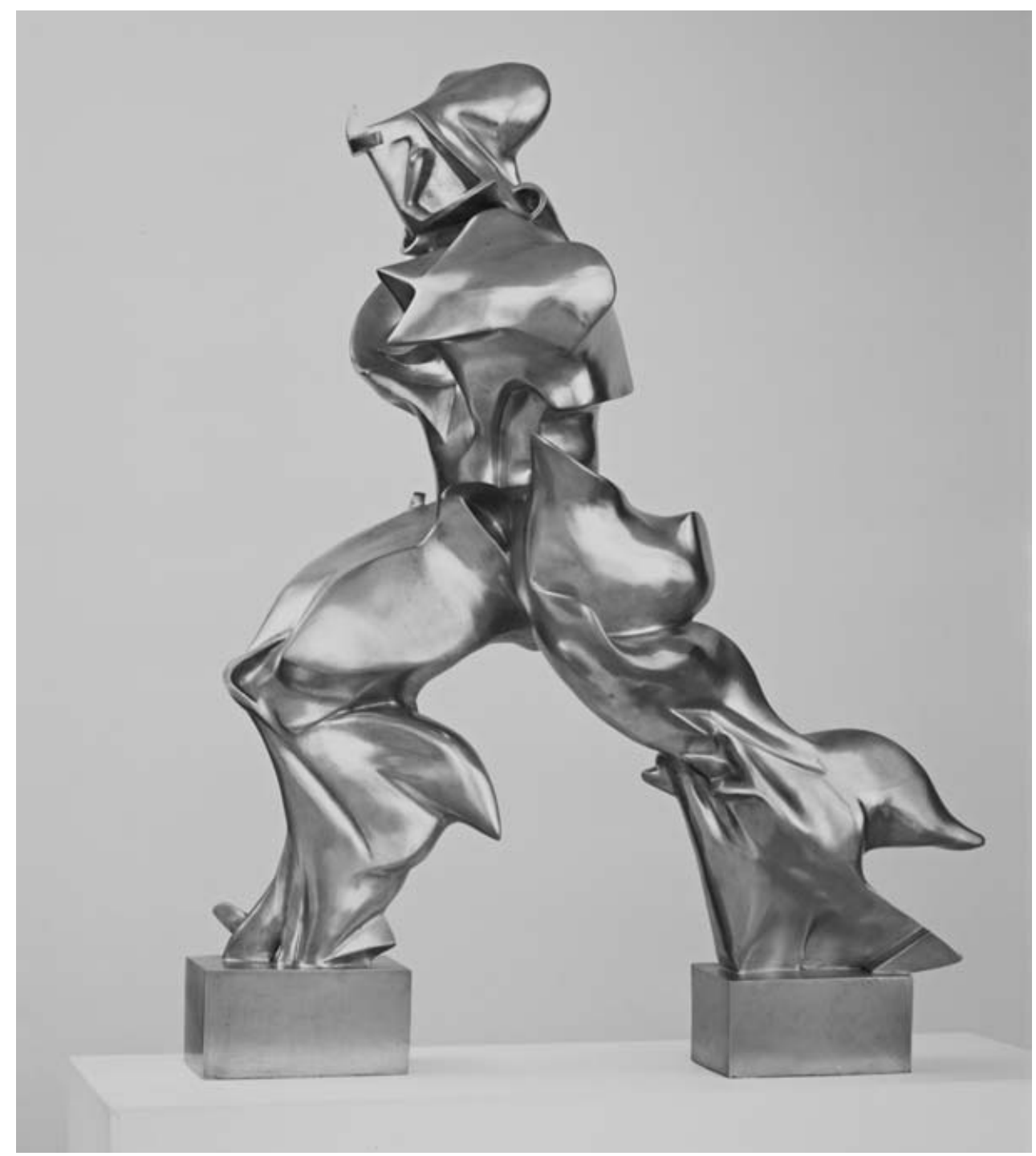

Fig. 3. Umberto Boccioni, Unique Forms of Continuity in Space, 1913, bronze. Museum of Modern Art, New York. Acquired through the Lillie P. Bliss Bequest. Digital Image (c) The Museum of Modern Art/Licensed by SCALA/Art Resource, NY.

infinite unfolding" (Boccioni 1975, 73). In defining a dynamic fourth dimension for Futurism in his 1914 treatise, Boccioni was claiming the fourth dimension for Futurism and reacting to the prominent role the spatial fourth dimension played in Cubist theory. 
In contrast to later interpretations that attempted to tie Picasso's Cubism and Apollinaire's criticism to the temporal fourth dimension of Einstein's space-time world, Cubism's fourth dimension basically signified a suprasensible spatial dimension that might hold a truth higher than that of visible reality. ${ }^{68} \mathrm{With}$ its roots in $n$-dimensional geometry and with significations ranging from geometry and science to philosophy, mysticism, and occultism, the fourth dimension generated a huge amount of popular literature in Europe and the United States. In tandem with the scientific issues discussed above, the possible existence of an additional dimension of space would certainly have encouraged Picasso's bold pictorial invention. In the Portrait of Kahnweiler, for example, the geometrical faceting of objects suggests a more complex reality beyond immediate perception. Picasso's painting, in fact, shares with contemporary geometrical diagrams of four-dimensional figures differently shaded angular components in ambiguous spatial relationships as well as a sense of shifting views of an object fused into one (fig. 4). Ultimately, the interpenetration of form and space - derived in large part from contemporary scientific ideas - denies the possibility of reading the painting's space as three-dimensional. ${ }^{69}$

Discussions of Picasso and the fourth dimension have hinged on the presence in his circle of the insurance actuary Maurice Princet as well as Apollinaire's declaration in his Les Peintres Cubistes that the fourth dimension was part of the "language of the modern studios" (Apollinaire 1944, 12). According to Apollinaire's text, the fourth dimension offered artists a rationale for distorting or deforming objects according to a higher law and for rejecting three-dimensional, one-point perspective, which now seemed quite irrelevant (Apollinaire 1944, 12; Henderson 1983, 75-89). In their 1912 book Du Cubisme Metzinger and Gleizes also discussed Cubism's new mobile perspectives in relation to Henri Poincaré's advocacy of perception using senses other than vision, i.e., tactile and motor sensations, and his idea that "motor space would have as many dimensions as we have muscles" (Poincaré 1902, 72-73). ${ }^{70}$

Poincaré and Princet are crucial figures for Arthur Miller in his recent book Einstein, Picasso: Space, Time and the Beauty That Causes Havoc. In contrast to the numerous authors who have attempted to find direct links or correlations between

\footnotetext{
${ }^{68}$ Duchamp was the one early twentieth-century artists who actually explored four-dimensional geometry itself, and his playful response to the fourth dimension in various guises is central to the Large Glass project (see Henderson 1983, chap. 3; and Henderson 1998; see also Adcock 1983).

${ }^{69}$ For a fuller discussion of this issue, see Henderson 1983, 57-59. Artist Tony Robbin has made a careful analysis of the geometry in Jouffret's Traité élémentaire and argues convincingly in his forthcoming Yale University Press book that Picasso's Portrait of Kahnweiler, among other works, responds directly to Jouffret's technique of X-raylike "see-through" views of complex four-dimensional solids. The moment when such formal comparisons are convincing is 1910-1911, unlike the case for an earlier impact made by Arthur Miller in Einstein, Picasso (see n. 71).

${ }^{70}$ For Gleizes' and Metzinger's discussion, see Herbert 1964, 8; see also Henderson 1983, 81-83, where this connection was first proposed. On Poincaré's importance for Cubism as well as Duchamp, see ibid., 71-73, 81-85, 93-99; chap. 4.
} 


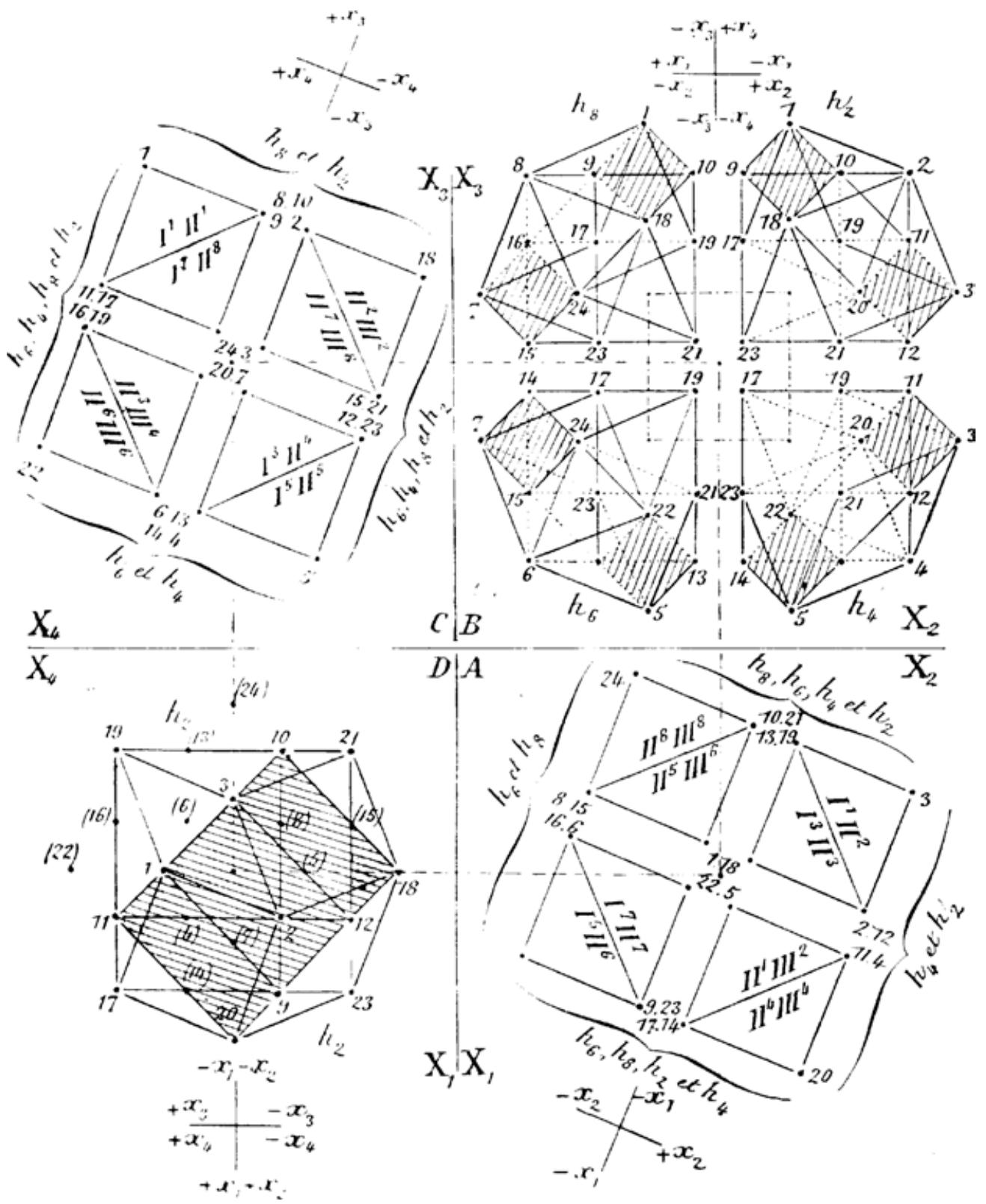

Fig. 4. "Plane projections of the sixteen fundamental octahedrons of the ikosatetrahedroid." From E. Jouffret, Traite élémentaire de la géométrie à quatre dimensions (Paris: Gauthier-Villars, 1903), fig. 40.

Picasso and Einstein, Miller explores the "parallel biographies" of the two, arguing for their common sources in the figure of Henri Poincaré and the field of fourdimensional geometry (via Minkowski and Poincaré for Einstein, via Princet for 
Picasso). ${ }^{71}$ Nonetheless, Miller's title still evokes for the potential reader the myth that some historical link existed between these cultural icons. As Duchamp observed in a 1967 interview, "The public always needs a banner; whether it be Picasso, Einstein, or some other" (Cabanne [1967] 1971, 26). From the vantage point of the 1960s, Duchamp was summing up a phenomenon he had observed developing since the 1920s: the emergence of the perception of Picasso as the modern artist and Einstein as the scientist of the twentieth century. ${ }^{72}$ Duchamp was an especially sensitive witness to this, since he knew personally that the art world of prewar Paris - including Cubism had involved a variety of artists, including himself, and that the science in question had not been Einstein's.

Along with Giedion's 1941 Space, Time, and Architecture, Apollinaire's Les Peintres Cubistes text on the fourth dimension played a definitive role in the emergence of the Cubism-Relativity myth in New York in the 1940s. Giedion had cited Apollinaire's discussion of the fourth dimension and identified it as time, even though the poet repeatedly referred to space (Giedion 1941, 357; Apollinaire 1944, 12). When The Cubist Painters was published in George Wittenborn's "Documents of Modern Art" series in 1944, its readers could easily have drawn a similar conclusion. Reflecting the goal of Wittenborn and series editor Robert Motherwell to establish modern art's legitimacy, the books of the series bore on the back cover a text emphasizing that modern art "assimilat[ed] the ideas and morphology of the twentieth century" and was "the expression of our own historical epoch" (Apollinaire 1944, back cover; italics mine). Here the stage was set for what became the classic confusion between Cubism then and science now. Kepes' references to space-time in his Language of Vision of the same year - along with Moholy-Nagy's even more influential celebration of Einstein and space-time as basic to understanding of modern life and art in his 1947 Vision in Motion - only exacerbated the situation.

By the 1940s both the spatial fourth dimension and ether physics had faded from popular consciousness, occluded by Einstein and Relativity Theory. Largely forgotten

\footnotetext{
${ }^{71}$ Miller, however, is too eager to identify the primary impetus for the development of Cubism as fourdimensional geometry, as preached to Picasso by the insurance actuary Princet. Miller places this moment too early (i.e., the Demoiselles d'Avignon in 1907) and gives too little credence to sources within art that were also driving Picasso's rethinking of painting. The image of Picasso simply as Princet's willing geometry student in 1907 is hard to accept, even for someone who believes the fourth dimension played a vital role in the subsequent evolution of the style. Any geometrically oriented form in 1907 is for Miller a sure sign of the impact of Princet and Poincaré - as is the mere mention of "tactility" by Picasso, Braque and anyone else (see, e.g., Miller 2001, 131, 165). In both cases he misses the central role of Picasso's artistic milieu, in which both African art and Cézanne encouraged the geometricizing of form and in which the issue of tactility in painting was a key concern, separate from Poincaré's discussions of "tactile and motor spaces" (Poincaré 1902, 72-73).

72 The Cubism-Relativity myth also discouraged scholars from investigating the bonafide impact of Einstein and the "space-time" world of Relativity Theory after its popularization began in 1919. These sites of response ranged from 1920s Berlin and the Paris of the Surrealists during the 1920s-1930s to New York in the 1940s and the kinetic art scene that first coalesced in Paris in the 1950s. (Gamwell 2002, chap. 10, expands upon my initial work on space-time and art in the 1920s [Henderson 1983]). Parkinson 2005 provides the first detailed examination of the Surrealist response to Relativity Theory. The new introduction for the MIT reprint of Henderson 1983, to appear in 2005, addresses the impact of Einstein and space-time on artists in New York and Paris in the 1950 s.
} 
were the scientific heroes of the pre-World War I era in France: the Curies, Poincaré, and science popularizer Gustave Le Bon, as well as Röntgen, Rutherford, Lodge, and Crookes. Lodge and Crookes, along with Flammarion - with their openness to the occult and involvement in the Society for Psychical Research - are pointed reminders of the wider range of activities that were often classed as "science" in the late nineteenth and the early twentieth century. Occultists regularly drew on the latest science to support their causes, particularly in the linkages regularly made between X-rays and spirit photography, radioactivity and alchemy, telegraphy and telepathy, and, as noted earlier, electromagnetism and Magnetism. ${ }^{73}$ Such analogies were also drawn from the side of science, as in Crookes' prominent declaration in his 1898 Presidential Address before the British Association for the Advancement of Science that "ether vibrations have powers and attributes equal to any demand - even to the transmission of thought" (Crookes 1899, 31).

That capability of vibratory thought transfer attributed to the ether was vital to the art theory of the painters Kandinsky and František Kupka, who conceived their abstract canvases as the source of vibrations meant to resonate in a viewer (see, e.g., Henderson 2002). ${ }^{74}$ Similarly, the poet Ezra Pound responded to the theme of ethereal telegraphy/telepathy, comparing artists and poets to antennae "on the watch for new emotions, new vibrations sensible to faculties as yet ill understood" (Pound 1912, 500). As in the case of these modernists - along with the writings of Cubists, Futurists, and Duchamp - the operative words that emerge from analyzing early twentieth-century cultural discourse are not space-time and relativity, but rather terms such as invisible, energy, ether, vibration, and fourth dimension. Late classical ether physics - not relativity theory was the armature of the cultural matrix that stimulated the imaginations of modern artists and writers before the later 1910s and 1920s. Scholars of early modernism in general will surely benefit by turning their attention to this long-eclipsed, but vitally important, moment in the history of science and culture. "Sifted science will do your arts good," James Joyce declared in Finnegans Wake (Joyce 1959, 440), and, as this issue of Science in Context demonstrates, many modern artists clearly agreed. ${ }^{75}$

\footnotetext{
${ }^{73}$ See again n. 62. For these pairings, see Henderson 1998.

${ }^{74}$ On Kupka's engagement with science, see also Musée d'Orsay 2003.

${ }^{75}$ For a sampling of contemporary artists who have responded to science, see, e.g., Kemp 2000. Among young twenty-first century artists nourished by science, some of the most inventive responses are those of artist Matthew Ritchie; see, e.g., the exhibition catalog Matthew Ritchie: Proposition Player (Herbert 2003). In a variation on the tradition of Duchamp, who took a job in a library in order to read, and Smithson, who purchased paperback books on science, Ritchie found his inspiration in students' cast-off textbooks while working as a building superintendent near New York University. Responding to "the exhilaration of connecting with knowledge," Ritchie explains, "I looked at things like high temperature physics and biology and the relationship between them that collectively forms what we would like to believe is an objective truth about the nature of our times. All that was cooking away in my brain, and then bizarrely enough, I decided to force it into the brightly colored waistcoat of contemporary painting" (see ibid., 17).
} 


\section{References}

Adcock, Craig. 1983. Marcel Duchamp's Notes for the Large Glass: An n-Dimensional Analysis. Ann Arbor: UMI Research Press.

Aerts, Diederik, Ernest Mathijs, and Bert Mosselmans, eds. 1999. Science and Art [The Red Book of "Einstein Meets Magritte"]. Dordrecht: Kluwer Academic Publishers.

Antliff, Mark. 1993. Inventing Bergson: Cultural Politics and the Parisian Avant-Garde. Princeton: Princeton University Press.

Antliff, Mark and Patricia Leighton. 2001. Cubism and Culture. New York: Thames \& Hudson.

Apollinaire, Guillaume. 1944. The Cubist Painters: Aesthetic Meditations (1913). Edited by Robert Motherwell. Translated by Lionel Abel. New York: Wittenborn.

Arnheim, Rudolf. [1954] 1974. Art and Visual Perception: A Psychology of the Creative Eye [The New Version]. Berkeley: University of California Press.

Asendorf, Christoph. 1989. Ströme und Strahlen. Das langsame Verschwinden der Materie um 1900. Werkbund Archiv no.18. Giessen: Anabas-Verlag.

Ashton, Dore, ed. 1972. Picasso on Art: A Selection of Views. New York: Da Capo Press.

Badash, Lawrence. 1979. Radioactivity in America: Growth and Decay of a Science. Baltimore: Johns Hopkins University Press.

Baldassari. Anne. 1997. Picasso and Photography: The Dark Mirror. Paris: Flammarion.

Baxandall, Michael. 1985. Patterns of Intention: On the Historical Explanation of Pictures. New Haven: Yale University Press.

Benson, Donald R. 1984. "Facts and Fictions in Scientific Discourse: The Case of the Ether." Georgia Review 38:825-37.

Bergson, Henri. [1896] 1988. Matter and Memory. Translated by N. M. Paul and W. Scott Palmer. New York: Zone Books.

Blossfeldt, Karl. 1929. Art Forms in Nature: Examples from the Plant World Photographed Direct from Nature. New York: E. Weyhe.

Boccioni, Umberto, et al. [1910] 1973. "Technical Manifesto of Futurist Painting." In Futurist Manifestos. Edited by Umbro Apollonio, 27-31. Translated by Robert Brain, R. W. Flint, J. C. Higgitt, and Caroline Tisdall. New York: Viking Press.

Boccioni, Umberto. [1914] 1975. Dynamisme plastique: peinture et sculpture futuristes. Edited by Giovanni Lista. Translated by Claude Minot and Giovanni Lista. Lausanne: L'Age d'homme.

Bono, James J. 1990. "Science, Discourse, and Literature: The Role/Rule of Metaphor in Science." In Literature and Science: Theory and Practice, edited by Stuart Peterfreund, 59-89. Boston: Northeastern University Press.

Boudar, Gilbert and Michel Décaudin. 1983. Catalogue de la Bibliothèque de Guillaume Apollinaire. Paris: Editions du C.N.R.S.

Bredekamp, Horst. 2000. "Gazing Hands and Blind Spots: Galileo as Draftsman." Science in Context 13(3/4):423-62. Special issue on "Galileo in Context," edited by Jürgen Renn.

Bronowski, J[acob]. 1958. "The Creative Process.” Scientific American 199 (September):58-65.

Burnham, Jack. 1968. Beyond Modern Sculpture: The Effects of Science and Technology on the Sculpture of This Century. New York: George Braziller.

Cabanne, Pierre. [1967] 1971. Dialogues with Marcel Duchamp. Translated by Ron Padgett. New York: Viking Press.

Cantor, G. N. and M. J. S. Hodge. 1981. Conceptions of Ether: A Study in the History of Ether Theories 1740-1900. Cambridge: Cambridge University Press.

Celant, Germano. 1981. "Futurism and the Occult." Artforum 19 (January):36-42.

Clair, Jean, ed. 1993. L'âme au corps. Arts et sciences 1793-1993. Paris: Réunion des musées nationaux/Editions Gallimard. 
Clair, Jean, ed. 1999. Cosmos: From Romanticism to the Avant-garde. The Montreal Museum of Fine Arts/Munich: Prestel Verlag.

Clarke, Bruce. 2001. Energy Forms: Allegory and Science in the Era of Classical Thermodynamics. Ann Arbor: University of Michigan Press.

Coen, Esther. 1988. Umberto Boccioni. New York: Metropolitan Museum of Art.

Cook, Theodore Andrea. 1903. Spirals in Nature and Art: A Study of Spiral Formations Based on the Manuscripts of Leonardo da Vinci. London: J. Murray.

Cook, Theodore Andrea. 1914. The Curves of Life. London: Constable and Company.

Corry, Leo. 1999. "From Mie's Electromagnetic Theory of Matter to Hilbert's Unified Foundations of Physics." Studies in the History and Philosophy of Modern Physics 30 (June):159-83.

Courtenay, Philip. 1980. "Einstein and Art." In Einstein: The First Hundred Years, edited by Maurice Goldsmith, Alan Mackay, and James Woudhuysen, 145-57. Oxford: Pergamon Press.

Crary, Jonathan. 1990. Techniques of the Observer: On Vision and Modernity in the Nineteenth Century. Cambridge: MIT Press.

Crookes, William. 1899. Address by Sir William Crookes, President. Report of the Sixty-Eighth Meeting of the British Association for the Advancement of Science (1898), 3-33. London: John Murray.

Curie, Marie. 1904. "Radium and Radioactivity." The Century Magazine 67 (January):461-66.

Curtin, Deane W., ed. 1982. The Aesthetic Dimension of Science. 1980 Nobel Conference. New York: Philosophical Library.

Daston, Lorraine, ed. 2004. Things That Talk: Object Lessons from Art and Science. New York: Zone Books.

De Launay, L. 1908. "La Matière et l'éther." La Nature 36 (November 21):391-92.

Douglas, Charlotte. 1984. "Evolution and the Biological Metaphor in Modern Russian Art." Art Journal 44 (Summer):153-61.

Douglas, Charlotte. 1994. Kazimir Malevich. New York: Harry N. Abrams.

Douglas, Charlotte. 2002. "Energetic Abstraction: Ostwald, Bogdanov, and Russian Post-Revolutionary Art." In From Energy to Information: Representation in Science and Technology, Art, and Literature, edited by Linda Dalrymple Henderson and Bruce Clarke, 76-94. Stanford: Stanford University Press.

Duchamp, Marcel. 1973. Salt Seller: The Writings of Marcel Duchamp. Edited by Michel Sanouillet and Elmer Peterson. New York: Oxford University Press.

Duchamp, Marcel. 1983. Marcel Duchamp, Notes. Edited and translated by Paul Matisse. Boston: G. K. Hall.

Duncan, Robert Kennedy. 1905. The New Knowledge. New York: A. S. Barnes.

Durkheim, Emile. [1912] 1995. The Elementary Forms of Religious Life. Translated by Karen E. Fields. New York: Free Press.

Edgerton, Samuel Y. 1984a. "Galileo, Florentine Disegno, and the 'Strange Spottedness' of the Moon." Art Journal 44 (Fall):225-32.

Edgerton, Samuel Y., ed. 1984b. Art and Science: Part I, Life Sciences [special issue]. Art Journal 44 (Summer); Art and Science: Part II, Physical Sciences [special issue]. Art Journal 44 (Fall).

Ehrenzweig, Anton. 1967. The Hidden Order of Art: A Study in the Psychology of Artistic Form. Berkeley: University of California Press.

Einstein, Albert. 1922. Sidelights on Relativity. Translated by G. B. Jeffery and W. Perrett. New York: Henry Holt.

Elkins, James. 1995. “Art History and Images That Are Not Art.” Art Bulletin 77 (December):553-71.

Elkins, James. 1999. The Domain of Images. New York: Cornell University Press.

Elkins, James. 2003. Visual Studies: A Skeptical Introduction. New York: Routledge.

Emmer, Michele, ed. 1993. The Visual Mind: Art and Mathematics. Cambridge, MA: MIT Press.

Emmer, Michele, ed. 1996. "Special Section: The International Workshop on Art and Science." Leonardo: Journal of the International Society for the Arts, Sciences and Technology 29(1):17-42.

Emmer, Michele, ed. 2004. The Visual Mind II. Cambridge, MA: MIT Press.

Flam, Jack, ed. 1996. Robert Smithson: The Collected Writings. Berkeley: University of California Press.

Flammarion, Camille. [1900] 1901. The Unknown (L'Inconnu). New York: Harper \& Brothers. 
Focillon, Henri. [1934] 1948. The Life of Forms in Art. New York: Wittenborn, Schultz.

Foucault, Michel. [1969/1971] 1972. The Archeology of Knowledge and The Discourse on Language. Translated A. M. Sheridan Smith. New York: Pantheon Books.

Foucault, Michel. 1978. "Politics and the Study of Discourse." Ideology and Consciousness 3 (Spring):7-26. Frankel, Felice. 2002. Envisioning Science: The Design and Craft of the Science Image. Cambridge: MIT Press. Friedman, Alan J. and Carol C. Donley. 1985. Einstein as Myth and Muse. Cambridge: Cambridge University Press.

Fry, Edward F. 1966. Cubism. New York: McGraw-Hill.

Galerie Gmurzynska. 1999. Organica: The Non-Objective World of Nature in the Russian Avant-Garde of the 20th Century. Cologne: Galerie Gmurzynska.

Galison, Peter. 1997. Image and Logic: A Material Culture of Microphysics. Chicago: University of Chicago Press.

Galison, Peter and Lorraine Daston. 1992. "The Image of Objectivity.” In Representations 40 (Fall): 81-128.

Gamwell, Lynn. 2002. Exploring the Invisible: Art, Science, and the Spiritual. Princeton: Princeton University Press.

Geimer, Peter. 2000. "Noise or Nature: Photography of the Invisible around 1900." In Shifting Boundaries of the Real: Making the Invisible Visible, edited by Helga Nowotny and Martina Weiss, 119-35. Zurich: Hochschulverlag AG.

Giedion, Sigfried. 1941. Space, Time, and Architecture: The Growth of a New Tradition. Cambridge: Harvard University Press.

Gilot, Françoise and Carlton Lake. 1964. Life with Picasso. New York: McGraw-Hill.

Glasser, Otto. 1934. Wilhelm Conrad Röntgen and the Early History of the Röntgen Rays. Springfield, IL: Charles C. Thomas.

Glick, Thomas, ed. 1987. The Comparative Reception of Relativity. Dordrecht: D. Reidel Publishing.

Glinsky, Albert. 2000. Theremin: Ether Music and Espionage. Urbana: University of Illinois Press.

Goldberg, Stanley. 1984. Understanding Relativity: Origin and Impact of a Scientific Revolution. Boston: Birkhäuser.

Gombrich, E. H. 1960. Art and Illusion: A Study in the Psychology of Pictorial Representation. Princeton: Princeton University Press.

Gómez de la Serna, Ramón. 1929. "Completa y verídica historia de Picasso y el cubismo." Revista de Occidente 25 (July):63-102.

Graubard, Stephen R., ed. 1986. Art and Science. Lanham, MD: University Press of America. Originally published as Daedalus: Journal of the American Academy of Arts and Sciences 115 (Summer).

Greenberg, Clement. [1949] 1986. "Our Period Style." In Clement Greenberg: The Collected Essays and Criticism, edited by John O'Brian, 2:322-26. Chicago: University of Chicago Press.

Gustaffson, Lars, Susan Howard, and Lars Niklasson, eds. 1993. The Creative Process. Stockholm: Swedish Ministry of Education and Science.

Haeckel, Ernst. [1904] 1998. Kunstformen der Natur. Munich: Prestel Verlag.

Hafner, E. M. 1969. "The New Reality in Art and Science." Comparative Studies in Society and History 11 (October):385-97.

Hammer, Martin and Christina Lodder. 2000. Constructing Modernity: The Art and Career of Naum Gabo. New Haven: Yale University Press.

Harman, P. M. 1982. Energy, Force, Matter: The Conceptual Development of Nineteenth-Century Physics. Cambridge: Cambridge University Press.

Harrison, Charles. 1993. "Abstraction.” In Charles Harrison, Francis Frascina, and Gill Perry, Primitivism, Cubism, Abstraction: The Early Twentieth Century, 184-262. New Haven: Yale University Press.

Hayles, N. Katherine. 1984. The Cosmic Web: Scientific Field Models and Literary Strategies in the 20th Century. Ithaca: Cornell University Press.

Heisenberg, Werner. 1974. "The Tendency to Abstraction in Modern Art and Science." In Across the Frontiers, translated by Peter Heath, 142-53. New York: Harper \& Row. 
Henderson, Archibald. 1946. "Science and Art: An Approach to a New Synthesis." American Scientist 34 (Summer):453-63.

Henderson, Linda Dalrymple. 1971. “A New Facet of Cubism: 'The Fourth Dimension' and 'NonEuclidean Geometry' Reinterpreted." The Art Quarterly 34:410-33.

Henderson, Linda Dalrymple. 1983. The Fourth Dimension and Non-Euclidean Geometry in Modern Art. Princeton: Princeton University Press. New edition, Cambridge: MIT Press, 2005.

Henderson, Linda Dalrymple Henderson. 1986. "Mysticism, Romanticism, and the Fourth Dimension." In The Spiritual in Art: Abstract Painting 1890-1985," 212-37. Los Angeles: Los Angeles County Museum of Art/New York: Abbeville Press.

Henderson, Linda Dalrymple. 1988. "X Rays and the Quest for Invisible Reality in the Art of Kupka, Duchamp, and the Cubists." Art Journal 47 (Winter):323-40.

Henderson, Linda Dalrymple. 1998. Duchamp in Context: Science and Technology in the Large Glass and Related Works. Princeton: Princeton University Press.

Henderson, Linda Dalrymple. 1999. “The Large Glass Seen Anew: Reflections of Science and Technology in Marcel Duchamp's 'Hilarious Picture.”' Leonardo 32(2):113-26.

Henderson, Linda Dalrymple. 2002. "Vibratory Modernism: Boccioni, Kupka, and the Ether of Space." In From Energy to Information: Representation in Science and Technology, Art, and Literature, edited by Linda Dalrymple Henderson and Bruce Clarke, 126-49. Stanford: Stanford University Press.

Henderson, Linda Dalrymple. 2005. "Four-Dimensional Space or Space-Time?: The Emergence of the Cubism-Relativity Myth in New York in the 1940s." In The Visual Mind II, edited by Michele Emmer, 349-57. Cambridge: MIT Press (forthcoming).

Henderson, Linda Dalrymple and Bruce Clarke, eds. 2002. From Energy to Information: Representation in Science and Technology, Art, and Literature. Stanford: Stanford University Press.

Henning, Edward B. 1987. Creativity in Art and Science, 1860-1960. Cleveland: Cleveland Museum of Art.

Henry, Holly. 2003. Virginia Woolf and the Discourse of Science. Cambridge: Cambridge University Press.

Herbert, Lynn M., curator and ed. 2003. Matthew Ritchie: Proposition Player. Houston: Contemporary Arts Museum.

Herbert, Robert L. 1964. Modern Artists on Art. Englewood Cliffs, NJ: Prentice-Hall.

Herbert, Robert L. 1991. Georges Seurat. New York: Metropolitan Museum of Art.

Hess, David J., ed. 1997. Science Studies: An Advanced Introduction. New York: New York University Press. Heylighen, Francis, Johan Bollen, and Alexander Riegler, eds. 1999. The Evolution of Complexity [The Violet Book of "Einstein Meets Magritte"]. Dordrecht: Kluwer Academic Publishers.

Hicken, Adrian. 2002. Apollinaire, Cubism and Orphism. Aldershot, England: Ashgate.

Hoffmann, Roald. 1995. The Same and Not the Same. New York: Columbia University Press.

Hoffmann, Roald and Vivan Torrence. 1993. Chemistry Imagined: Reflections on Science. Washington: Smithsonian Institution Press.

Holton, Gerald. 1996. Einstein, History, and Other Passions. Cambridge: Harvard University Press.

Hopkins, David. 2000. After Modern Art 1945-2000. Oxford: Oxford University Press.

Houston, Edwin. 1892. "Cerebral Radiation.” Journal of the Franklin Institute 133 (June):488-97.

Houston, Edwin. [1895] 1909. "La Radiation cérébrale." In Albert de Rochas, L'Extériorisation de la sensibilité, Note G, 231-41. 6th ed. Paris: Bibliothèque Chacornac.

Hunt, Bruce J. 2002. "Lines of Force, Swirls of Ether." In From Energy to Information: Representation in Science and Technology, Art, and Literature, edited by Linda Dalrymple Henderson and Bruce Clarke, 99-113. Stanford: Stanford University Press.

Johnson, Martin. [1944] 1949. Art and Scientific Thought: Historical Studies Towards a Modern Revision of Their Antagonism. New York: Columbia University Press.

Jones, Caroline A. 2000. "The Modernist Paradigm: The Artworld and Thomas Kuhn." Critical Inquiry 26 (Spring):488-528.

Jones, Caroline A. and Peter Galison, eds. 1998. Picturing Science, Producing Art. New York: Routledge. Joyce, James. 1959. Finnegans Wake. New York: Viking Press. 
Kahnweiler, Daniel-Henry. 1949. The Rise of Cubism (1920). Translated by Henry Aronson. New York: Wittenborn, Schultz.

Kandinsky Wassily. [1911] 1973. Über das Geistige in der Kunst. Bern: Benteli Verlag.

Karmel, Pepe. 2003. Picasso and the Invention of Cubism. New Haven: Yale University Press.

Keller, Alex. 1983. The Infancy of Atomic Physics: Hercules in His Cradle. Oxford: Clarendon Press.

Kemp, Martin. 1990. The Science of Art: Optical Themes in Western Art from Brunelleschi to Seurat. New Haven: Yale University Press.

Kemp, Martin. 1996. "Doing What Comes Naturally: Morphogenesis and the Limits of the Genetic Code." Art Journal 55 (Spring):27-32.

Kemp, Martin. 1997. "Seeing and Picturing: Visual Representation in Twentieth-Century Science." In Science in the Twentieth Century, edited by John Krige and Dominique Pestre, 361-90. Amsterdam: Harwood Academic Publishers.

Kemp, Martin. 2000. Visualizations: the Nature Book of Art and Science. Berkeley: University of California Press.

Kepes, Gyorgy. 1944. The Language of Vision. Chicago: Paul Theobald.

Kepes, Gyorgy. 1956. The New Landscape in Art and Science. Chicago: Paul Theobald.

Kepes, Gyorgy, ed. 1965. Structure in Art and in Science. Vision + Value Series. New York: George Braziller.

Kepes, Gyorgy, ed. 1966. Module, Proportion, Symmetry, Rhythm. Vision + Value Series. New York: George Braziller.

Kevles, Bettyann Holzmann. 1997. Naked to the Bone: Medical Imaging in the Twentieth Century. New Brunswick, NJ: Rutgers University Press.

Knight, Nancy. 1986. “'The New Light': X Rays and Medical Futurism.” In Imagining Tomorrow: History, Technology and the American Future, edited by Joseph J. Corn, 10-34. Cambridge, MA: MIT Press.

Kragh, Helge. 1999. Quantum Generations: A History of Atomic Physics in the Twentieth Century. Princeton: Princeton University Press.

Kubler, George. 1962. The Shape of Time: Remarks on the History of Things. New Haven: Yale University Press.

Kubler, George. 1969. "Comment [on the Relations of Science and Art]." Comparative Studies in Society and History 11 (October): 398-402.

Kubler, George. 1985. Studies in Ancient American and European Art: The Collected Essays of George Kubler. Edited by Thomas F. Reese. New Haven: Yale University Press.

Kuhn, Thomas S. [1969] 1977. "Comment [on the Relations of Science and Art]. Comparative Studies in Society and History 11 (October):403-12. Reprinted in Kuhn, The Essential Tension, 340-51. Chicago: University of Chicago Press.

Kuhn, Thomas S. 1970. The Structure of Scientific Revolutions. Chicago: University of Chicago Press.

Laporte, Paul M. 1948. "The Space-Time Concept in the Work of Picasso." The Magazine of Art 41 (January):26-32.

Laporte, Paul M. 1949. "Cubism and Science." The Journal of Aesthetics and Criticism 7 (March): 24356.

Laporte, Paul M. 1966. "Cubism and Relativity, with a Letter of Albert Einstein." Art Journal 25 (Spring):246-48.

Latour, Bruno and Peter Weibel, eds. 2002. Iconoclash: Beyond the Image Wars in Science, Religion, and Art. Karlsruhe: ZKM/Cambridge: MIT Press.

Le Bon, Gustave. 1905. L'Évolution de la matière. Paris: Flammarion.

Le Bon, Gustave. 1906. "The Decay of Matter.” The Independent 61 (July 26):183-86.

Le Bon, Gustave. 1911. The Evolution of Matter. Translated by F. Legge. London: Walter Scott Publishing/New York: Charles Scribner's Sons.

Lee, Pamela. 2001. “'Ultramoderne': Or, How George Kubler Stole the Time in Sixties Art.” Grey Room 2 (Winter 2001):46-77.

Levy, Ellen K. and Berta M. Sichel, eds. 1996. Contemporary Art and the Genetic Code [special issue]. Art Journal 55 (Spring). 
Lodge, Oliver. 1904. "Electric Theory of Matter.” Harper's Monthly Magazine 109 (August):383-89.

Lodge, Oliver. 1909. The Ether of Space. London and New York: Harper \& Brothers.

Lodge, Oliver. 1913. Continuity. London: J. M. Dent \& Sons.

Lodge, Oliver. 1920. "The Ether Versus Relativity.” Fortnightly Review 113 (January): 54-59.

Loeb, Arthur L. 1976. Space Structures: Their Harmony and Counterpoint. Reading, MA: Addison-Wesley.

Looper, Matthew G. 1995. "The Pathology of Painting: Tuberculosis as a Metaphor in the Art Theory of Kazimir Malevich." Configurations 3 (Winter):27-46.

Magie, William. 1912. "The Primary Concepts of Physics." Science n.s. 35 (February):281-93.

Mareschal, G. 1897. "Photographie d'éffluves humaines et magnétiques." La Nature 25 (October 30):34950.

Marshall, William. 1914. "The Theory of Relativity and the New Mechanics." Popular Science Monthly 84 (May):434-48.

Martin, Marianne W. 1969. "Futurism, Unanimism and Apollinaire." Art Journal 28 (Spring):258-68.

Max-Planck-Institut für Wissenschaftsgeschichte. 2002. Experimental Cultures: Configurations Between Science, Art, and Technology, 1830-1950. Berlin: MPIWG.

Mermoz, Gérard. 1983. "On the Synchronisation Between Artistic and Scientific Ideas and Practices: An Exploration of Hypotheses, 1900-1930." In Common Denominators in Art and Science, edited by Martin Pollock, 134-44. Aberdeen: Aberdeen University Press.

Miller, Arthur I. [1984] 1986. Imagery in Scientific Thought: Creating Twentieth-Century Physics. Cambridge, MA: MIT Press.

Miller, Arthur I. [1996] 1999. Insights of Genius: Imagery and Creativity in Science and Art. Cambridge, MA: MIT Press.

Miller, Arthur I. 2001. Einstein, Picasso: Space, Time, and the Beauty That Causes Havoc. New York: Basic Books.

Mitchell, Timothy. 1977. "Bergson, Le Bon, and Hermetic Cubism." Journal of Aesthetics and Art Criticism 36 (Winter): $175-83$.

Moffat, Isabelle. 2000. "“A Horror of Abstract Thought': Postwar Britain and Hamilton's 1951 Growth and Form Exhibition." October 94 (Fall):89-112.

Moholy-Nagy, L. 1947. Vision in Motion. Chicago: Paul Theobald.

Mook, Delo, and Thomas Vargish. 1999. Inside Modernism: Relativity Theory, Cubism, Narrative. New Haven: Yale University Press.

Musée d'Orsay, Paris. 2003. Aux origines de l'abstraction 1880-1914. Paris: Editions de la Réunion des Musées Nationaux.

Nye, Mary Jo. 1972. Molecular Reality: A Perspective on the Scientific Work of Jean Perrin. London: Macdonald.

Nye, Mary Jo. 1974. "Gustave Le Bon's Black Light: A Study in Physics and Philosophy in France at the Turn of the Century." In Historical Studies in the Physical Sciences 4:163-95.

Paalen, Wolfgang. 1945. Form and Sense. Problems of Contemporary Art, no.1, 23-30. New York: Wittenborn.

Parkinson, Gavin. 2005. Surrealism and Science. New Haven: Yale University Press.

Peterfreund, Stuart, ed. 1990. Literature and Science: Theory and Practice. Boston: Northeastern University Press.

Petrie, Brian. 1974. "Boccioni and Bergson." The Burlington Magazine 116 (March):140-47.

Poincaré, Henri. 1902. La Science et l'hypothèse. Paris: Flammarion.

Pollock, Martin, ed. 1983. Common Denominators in Art and Science. Aberdeen: Aberdeen University Press.

Porter, Roy. 1994. "The Two Cultures Revisted." Cambridge Review 115 (November):74-80.

Pound, Ezra. 1912. "The Wisdom of Poetry." Forum 47 (April): 329-32.

Prigogine, Ilya. 1999. "Einstein and Magritte: A Study of Creativity." In Einstein Meets Magritte: An Interdisciplinary Reflection [The White Book of "Einstein Meets Magritte"], edited by Aerts, Diederik, Jan Broekaert, and Ernest Mathijs, 99-105. Dordrecht: Kluwer Academic Publishers.

Prigogine, Ilya. 2001. L'Homme devant l'incertain. Paris: Editions Odile Jacob.

Reynolds, Ann. 2003. Robert Smithson: Learning from New Jersey and Elsewhere. Cambridge: MIT Press. 
Richardson, John (with Marilyn McCully). 1996. A Life of Picasso, Volume II: 1907-1917. NewYork: Random House.

Richardson, John Adkins. 1971. Modern Art and Scientific Thought. Urbana: University of Illinois Press.

Richardson, John Adkins. 1985. "Essay Review - Art, Science, and Modernity." Journal of Aesthetics and Art Criticism 19:89-99.

Rieser, Dolf. 1972. Art and Science: Modes of Thinking, Visual Perception and Artistic Vision, Art Forms in Nature, Art and the Unconscious Mind. London: Studio Vista.

Ritterbush, Philip C. 1968. The Art of Organic Forms. Washington, DC: Smithsonian Institution Press.

Robbin, Tony. 1992. Fourfield: Computers, Art, and the Fourth Dimension. Boston: Bulfinch Press.

Robbins, David, ed. 1990. The Independent Group: Postwar Britain and the Aesthetics of Plenty. Cambridge, MA: MIT Press.

Romains. Jules. 1913. La Vie unanime. Paris: Mercure de France.

Root-Bernstein, Robert. 2000. “Art Advances Science.” Nature 407 (September 14):134.

Root-Bernstein, Robert. 2004. "ArtScience: The Essential Connection.” Leonardo 37(2):93-94.

Root-Bernstein, Robert and Michelle. 1999. Sparks of Genius: The Thirteen Thinking Tools of the World's Most Creative People. Boston: Houghton-Mifflin.

Roslak, Robyn S. 1991. "The Politics of Aesthetic Harmony: Neo-Impressionism, Science, and Anarchism." The Art Bulletin 73 (September):381-90.

Rubin, William. 1972. Picasso in the Collection of the Museum of Modern Art. New York: Museum of Modern Art.

Rutherford, Ernest. 1904. "Disintegration of the Radioactive Elements." Harper's Monthly Magazine 108 (January):279-84.

Schapiro, Meyer. 2000. "Einstein and Cubism: Science and Art." In The Unity of Picasso's Art, 49-149. New York: George Braziller.

Schmidt, Georg, and Robert Schenk, eds. 1960. Kunst und Naturform. Basel: Basilius Presse.

Shlain, Leonard. 1991. Art and Physics: Parallel Visions in Space, Time, and Light. New York: William Morrow.

Smith, Cyril Stanley. 1981. A Search for Structure: Selected Essays on Science, Art, and History. Cambridge: MIT Press.

Snow, C. P. [1959/1964] 1998. The Two Cultures. Introduction by Stefan Collini. Cambridge: Cambridge University Press.

Snyder, Carl. 1903. "The World Beyond Our Senses.” Harper's Monthly Magazine 107 (June):11720.

Sommerer, Christa, and Laurent Mignonneau, eds. 1998. Art@Science. Vienna: Springer-Verlag.

Spector, Tami I. and Joachim Schummer, eds. 2003. Special Issue: Aesthetics and Visualization in Chemistry. Hyle: International Journal for Philosophy of Chemistry 9.

Stafford, Barbara Maria. 1996. Good Looking: Essays on the Virtue of Images. Cambridge, MA: MIT Press.

State Russian Museum. 2000. In Malevich's Circle: Confederates, Students, Followers in Russia 1920s-1950s. St. Petersburg: Palace Editions.

Steinberg, Leo. [1953] 1972. "The Eye is Part of the Mind." Partisan Review 20 (March-April): 194-212. Reprinted in Steinberg, Other Criteria, 289-306. London: Oxford University Press.

Steinberg, Leo. 1986. "Art and Science: Do They Need to be Yoked?” In Art and Science, edited by Stephen R. Graubard, 1-16. Lanham, MD: University Press of America.

Sund, Judy. 1984. "Fernand Léger and Unanimism: 'Where There's Smoke...."' Oxford Art Journal 7(1):49-56.

Thompson, D’Arcy Wentworth. [1917] 1942. On Growth and Form. Rev. ed. Cambridge: Cambridge University Press

Thomson, J. J. 1910. “Address by the President, Sir J. J. Thomson.” In Report of the Seventy-Ninth Meeting of the British Associaton for the Advancement of Science (1909), 3-29. London: John Murray.

Topper, David. 1988. "On the Ghost of Historiography Past." Leonardo 21(1):76-78. 
Trulove, James Grayson, ed. 2000. Dancing in the Landscape: The Sculpture of Athena Tacha. Washington, DC: Editions Ariel.

Vitz, Paul C. and Arnold B. Glimcher. 1984. Modern Art and Modern Science: The Parallel Analysis of Vision. New York: Praeger Publishers.

Waddington, C. H. [1969] 1970. Behind Appearance: A Study of the Relations Between Painting and the Natural Sciences in This Century. Cambridge: MIT Press.

Wechsler, Judith. 1978a. "Gyorgy Kepes.” In Hayden Gallery, MIT, Gyorgy Kepes: The MIT Years, 19451977, 7-19. Cambridge, MA: MIT Press.

Wechsler, Judith, ed. 1978b. On Aesthetics in Science. Cambridge: MIT Press.

Weyl, Hermann. 1952. Symmetry. Princeton: Princeton University Press.

Whyte, Lancelot Law, ed. 1951. Aspects of Form: Symposium on Form in Nature and Art. Bloomington: Indiana University Press.

Wilson, Stephen. 2002. Information Arts: Intersections of Art, Science, and Technology. Cambridge, MA: MIT Press.

Winter, Amy. 2003. Wolfgang Paalen: Artist and Theorist of the Avant-Garde. Westport, CN: Praeger.

Zeki, Semir. 1999. Inner Vision: An Exploration of Art and the Brain. Oxford: Oxford University Press. 